\title{
6. PRIMARY AND SECONDARY VARIATIONS IN MAJOR AND TRACE ELEMENT GEOCHEMISTRY OF THE LOWER SHEETED DIKE COMPLEX: HOLE 504B, LEG 140 ${ }^{1}$
}

\author{
Evelyn Zuleger, ${ }^{2}$ Jeffrey C. Alt, ${ }^{3}$ and Jorg Erzinger ${ }^{2}$
}

\begin{abstract}
Rocks of the lower sheeted dike complex of Hole 504B sampled during Leg 140 were analyzed for major and trace element compositions to investigate the effects of igneous processes and hydrothermal alteration on the compositions of the rocks. The rocks are relatively uniform in composition and similar to the shallower dikes. They are moderately evolved mid-ocean-ridge

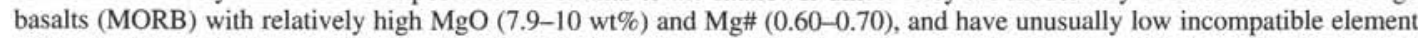
contents $\left(\mathrm{TiO}_{2}=0.42-1.1 \mathrm{wt} \%, \mathrm{Zr}=23-62 \mathrm{ppm}\right)$. Discrete compositional intervals in the hole reflect varying degrees of differentiation, and olivine and plagioclase accumulation in the rocks, and may be related to injection of packets of dikes having similar compositions. Systematic depletions of total $\mathrm{REE}, \mathrm{Zr}, \mathrm{Y}, \mathrm{TiO}_{2}$, and $\mathrm{P}_{2} \mathrm{O}_{5}$ in centimeter-size patches are most likely attributed to exclusion of highly differentiated, late-stage interstitial liquids from small portions of the rocks.

The rocks exhibit increased $\mathrm{H}_{2} \mathrm{O}^{+}$reflecting hydrothermal alteration. Replacement of primary plagioclase by albite and oligoclase led to local gains of $\mathrm{Na}_{2} \mathrm{O}$, losses of $\mathrm{CaO}$, and slightly positive Eu anomalies. Some mobility of $\mathrm{P}_{2} \mathrm{O}_{5}$ led to minor increases and decreases in $\mathrm{P}_{2} \mathrm{O}_{5}$ contents, and some local mobility of Ti may have occurred during alteration of titanomagnetite to titanite. Higher temperatures of alteration in the lower sheeted dikes led to breakdown of pyroxene and sulfide minerals and losses of $\mathrm{Zn}, \mathrm{Cu}$, and $\mathrm{S}$ to hydrothermal fluids. Later addition of anhydrite to the rocks in microfractures and replacing plagioclase caused local increases in sulfur contents. The lower sheeted dikes are a major source of metals to hydrothermal fluids for the formation of metal sulfide deposits on and within the seafloor.
\end{abstract}

\section{INTRODUCTION}

Understanding the structure, tectonics, petrology, and chemical alteration processes in the oceanic crust are among the most important goals of the Ocean Drilling Program (ODP). Our knowledge of the nature of oceanic basement is mainly drawn from studies of ophiolite complexes, remote geophysical surveys, and studies made on dredged or cored samples from the ocean floor. A generally layered model of the ocean crust has been proposed based on these studies (e.g., Raitt, 1963; Fox and Stroup, 1981). In this layered model, pelagic sediments (seismic Layer 1) cover a volcanic sequence of pillowed and massive basalts and breccias (Layer 2A and 2B). This upper section grades downward into a sheeted diabasic dike complex (Layer 2C), which is underlain by a plutonic sequence of gabbros and ultramafic cumulates (Layer 3). The volcanic section is generally altered at low temperatures up to greenschist conditions, and the underlying sheeted dikes are altered under greenschist grading downward to amphibolite facies conditions in the uppermost gabbros.

The only oceanic drill hole that clearly penetrates through the lavas of Layers 2A and 2B into the sheeted dike complex of Layer 2C is Deep Sea Drilling Project (DSDP)/ODP Hole 504B. Late in 1991, ODP Leg 140 returned to Hole 504B and drilled the hole $379 \mathrm{~m}$ deeper into the sheeted dike complex to a total depth of 2000.4 meters below seafloor (mbsf) (Figs. 1 and 2). This chapter presents the chemical compositions of the basement rocks from Hole 504B recovered during Leg 140, and discusses some of the processes responsible for the variations in their compositions.

\footnotetext{
${ }^{1}$ Erzinger, J., Becker, K., Dick, H.J.B., and Stokking, L.B. (Eds.), 1995. Proc. ODP Sci. Results, 137/140: College Station, TX (Ocean Drilling Program).

${ }^{2}$ Institut für Geowissenschaften und Lithosphärenforschung, Universităt Giessen, Senckenbergstrasse 3, 6300 Giessen, Federal Republic of Germany.

${ }^{3}$ Department of Geological Sciences, 1006 C.C. Little Building, University of Michigan, Ann Arbor, MI 48109-1063, U.S.A.
}

\section{SITE 504}

Hole 504B is located in 5.9-m.y.-old crust, $201 \mathrm{~km}$ south of the intermediate spreading-rate Costa Rica Rift (Fig. $1 ; 1^{\circ} 13.611^{\prime} \mathrm{N}$, $83^{\circ} 43.818^{\prime} \mathrm{W}$; water depth $3460 \mathrm{~m}$ ). Hole 504B is the deepest hole drilled into oceanic basement, penetrating $274.5 \mathrm{~m}$ of sediments, a 571.5-m volcanic section, a 209-m transition zone (TZ), and extending $954.5 \mathrm{~m}$ into a sheeted dike complex (SDC) (Fig. 2). Changes in alteration mineralogy with depth in the dikes, the increasing average grain size downward, the absence of glassy chilled dike margins in the lower dikes, and seismic data all indicate that, after the drilling on Leg 140, the hole now penetrates the lowermost portion of the sheeted dike complex, close to the transition downward from dikes to gabbros (Shipboard Scientific Party, 1988; 1992).

The upper $300 \mathrm{~m}$ of the volcanic section suffered oxidative alteration at high seawater/rock ratios and low temperatures $\left(<100^{\circ} \mathrm{C}\right)$. Nonoxidative alteration affected the lower volcanic section at low water/ rock ratios and possibly somewhat higher temperatures (up to $150^{\circ} \mathrm{C}$ ). Greenschist mineral assemblages abruptly appear at $898 \mathrm{mbsf}$, and are present to the bottom of the hole (Fig. 2) (Alt et al., 1986; Alt et al., 1989; Shipboard Scientific Party, 1992). Rocks recovered from Hole $504 \mathrm{~B}$ on Leg 140 are generally similar to those in the immediately overlying dikes (Shipboard Scientific Party, 1992). The Leg 140 rocks are affected by a pervasive slight background alteration, and are generally $10 \%-20 \%$ recrystallized. Locally the rocks are more intensively recrystallized (up to $80 \%-100 \%$ ) in centimeter-size alteration halos along chlorite and actinolite veins and in irregularly shaped "patches" up to several centimeters across. Increasing amounts of actinolite downward in the dikes, and the local presence of hornblende and secondary anorthite in the lower dikes, indicate higher temperatures of hydrothermal alteration in the lower dikes (Alt et al., this volume; Laverne et al., this volume).

The rocks recovered from Hole 504B prior to Leg 140 are variably plagioclase-olivine-clinopyroxene phyric, and commonly contain accessory $\mathrm{Cr}$-spinel. With the exception of two more-enriched units, the rocks are uniform in composition, interpreted to reflect a near steadystate magma chamber (Natland et al., 1983). The rocks are characterized by an unusual depletion in incompatible elements $(\mathrm{Ti}, \mathrm{Nb}, \mathrm{Zr}$, 


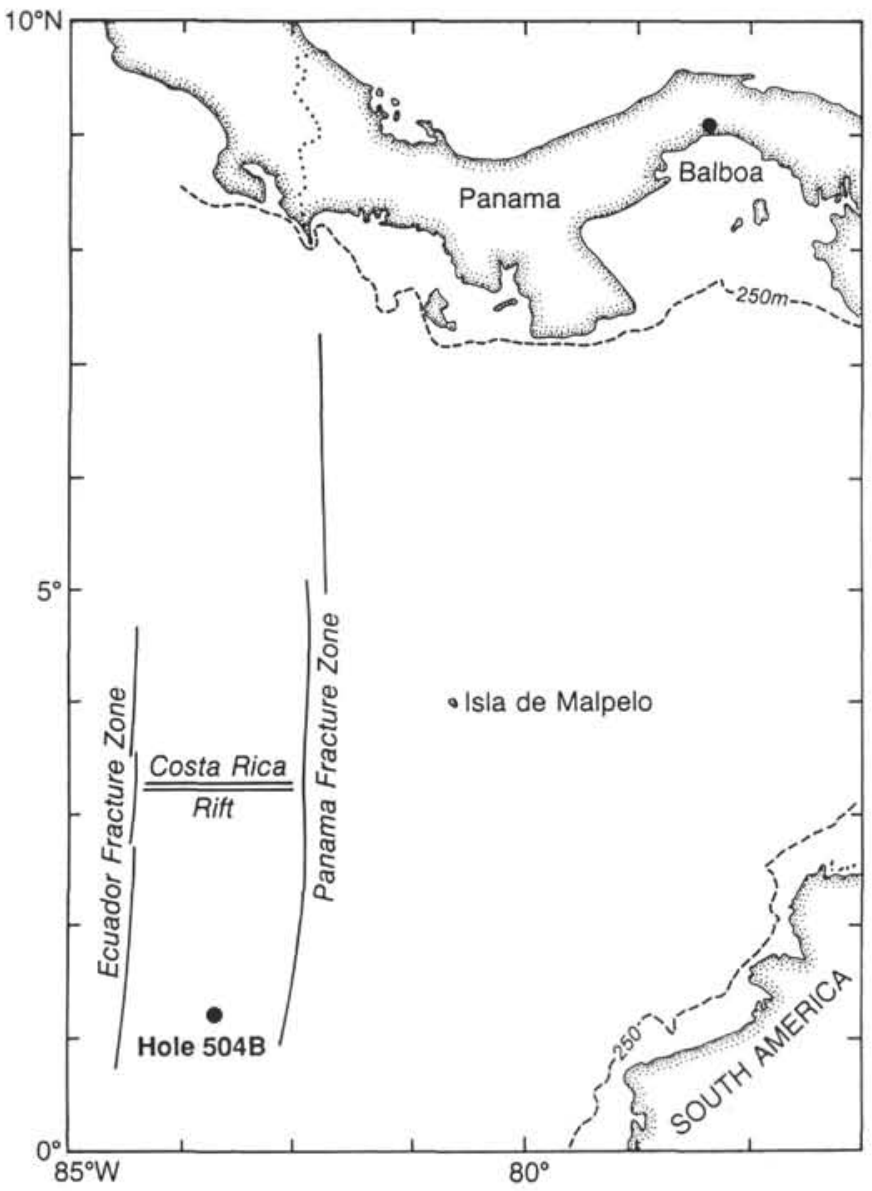

Figure 1. Location of DSDP/ODP Hole 504B south of the Costa Rica Rift in the eastern Pacific Ocean.

Y) and by incompatible element ratios similar to those of normal abyssal tholeiites (Autio and Rhodes, 1983; Emmermann, 1985; Hubberten et al., 1983).

\section{MAJOR AND TRACE ELEMENT COMPOSITION}

\section{Analytical methods}

This study is based on chemical data obtained for 85 whole rock samples, representing $62 \%$ of the 59 lithologic units recovered during Leg 140. Forty samples represent the freshest possible (i.e., the macroscopically least altered basalts, which are dark gray in color and have no visible veins or alteration discoloration). Any more intensively altered portions of the rocks or veins in the rocks were systematically removed by sawing prior to grinding for analysis. Throughout the following, these samples are referred to as "fresh rocks," and are listed as " $D$ " (for dark gray) in Table 1. Another 16 samples exhibit a slightly lighter gray color and are affected by more intensive background alteration, and are listed as "L" (for light gray) in Table 1. Many of the latter are from fine-grained dike margins with abundant veins, and the more intensive alteration may actually represent coalescing of alteration halos around multiple veins. Twenty-three samples represent highly altered rocks, that is, light gray to greenish alteration halos along veins and alteration patches (" $\mathrm{H}$ " and "P," respectively, in Table 1). Six samples were cut so that both the intensively altered patch or halo and the immediately adjacent dark gray host rock could be analyzed and compared (labeled A and B in Table 1).

After the samples were washed with distilled water, dried, and crushed to $<1 \mathrm{~mm}$, they were powdered in an agate mill to a grain size $<30 \mu \mathrm{m}$ suitable for analysis. The following techniques were used.

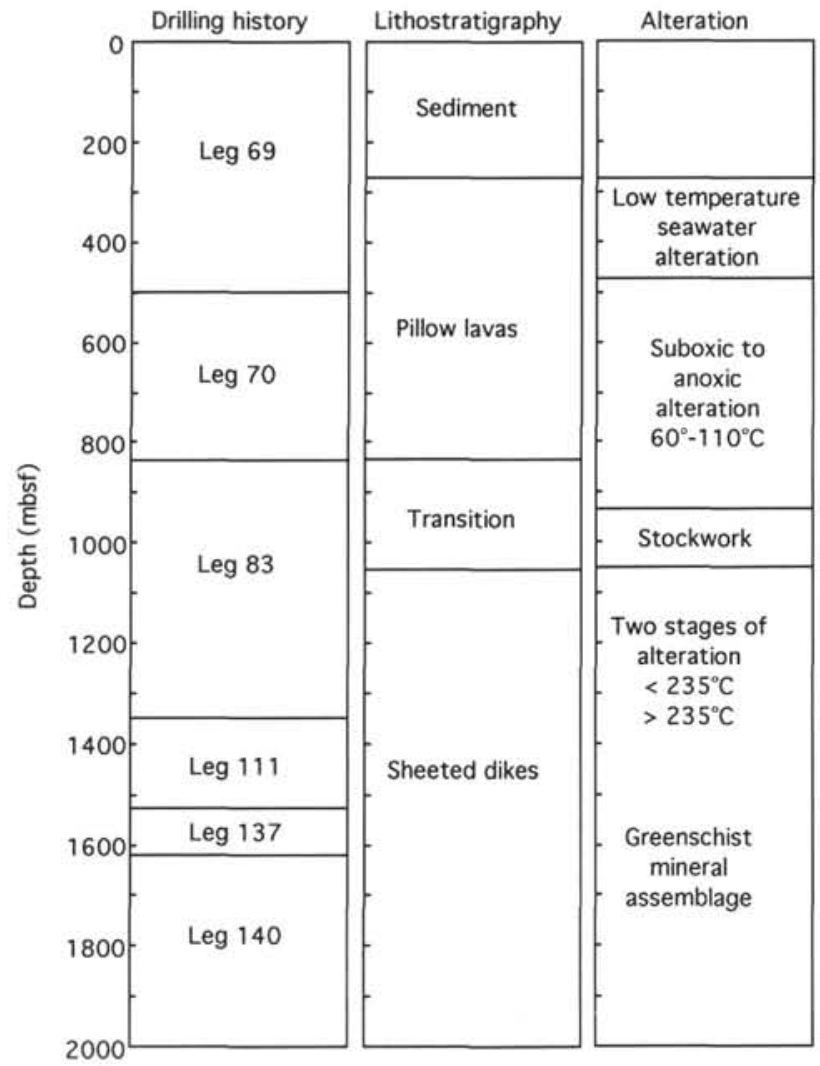

Figure 2. Lithostratigraphic and alteration summary, Hole 504B.

1. The major element oxides ( $\mathrm{Si}, \mathrm{Ti}, \mathrm{Al}, \mathrm{Fe}, \mathrm{Mn}, \mathrm{Mg}, \mathrm{Ca}, \mathrm{Na}, \mathrm{P}$, $\mathrm{K}$ ) were analyzed by X-ray fluorescence (XRF) on samples prepared as fused glass beads of lithium metaborate (rock to flux ratio 1:4) using a Phillips PW 1400 computerized spectrometer for intensity measurements and the alphas program to calculate concentrations.

2. $\mathrm{Fe}^{2+}$ was analyzed by manganometric titration.

3. $\mathrm{H}_{2} \mathrm{O}^{+}$and $\mathrm{CO}_{2}$ were measured on a Rosemount CWA 5003 analyzer.

4. S was determined on a Leco sulfur Sc 132 analyzer.

5. Measurements of $\mathrm{Cr}, \mathrm{Ni}, \mathrm{Cu}, \mathrm{Zn}, \mathrm{Ga}, \mathrm{Rb}, \mathrm{Sr}, \mathrm{Y}, \mathrm{Zr}, \mathrm{Nb}, \mathrm{Pb}, \mathrm{Th}$, and $\mathrm{Ba}$ were conducted by XRF on pressed powder pellets. The rhodium compton peak of the X-ray tube was used for matrix correction.

6. The rare earth elements (REE) were analyzed by optical emission spectroscopy (OES) using an inductively coupled plasma (ICP) for excitation. For this purpose the REE had to be quantitatively extracted by rock dissolution and concentrated using a chromatographic technique (Zuleger and Erzinger, 1988).

7. The mineral composition of selected samples was determined using a quantitative phase analysis procedure on a Siemens D $501 \mathrm{X}$ ray diffractometer (XRD) described by Emmermann and Lauterjung (1990). Only 31 samples could be analyzed by this method due to the small sample amounts remaining after chemical analysis.

Table 1 summarizes the chemical compositions of the 85 rock samples analyzed for this study, and Table 2 shows the REE data of selected samples. The values for $\mathrm{K}_{2} \mathrm{O}(<0.05 \%), \mathrm{CO}_{2}(<0.1 \%), \mathrm{Rb}$, $\mathrm{Pb}, \mathrm{Th}, \mathrm{Nb}(<5 \mathrm{ppm})$, and $\mathrm{Ba}(<20 \mathrm{ppm})$ were found to be below the detection limit of the methods used, and are hence not reported. The precision of major and trace element determination was tested by duplicate measurements on selected samples. The accuracy was checked by carrying the international reference rock BHVO-1, and the Leg 140 interlaboratory standard Bas 140 (Sparks and Zuleger, this volume) as unknowns through the whole procedure. The chemical results are given in Table 3 along with the analytical errors and 
recommended concentration values (Govindaraju, 1989). The analytical accuracy of different methods is given in Table 4. Also given are $\mathrm{Fe}_{2} \mathrm{O}_{3 \mathrm{~T}}$ (total iron calculated as $\left.\mathrm{Fe}_{2} \mathrm{O}_{3}\right)$, FM-value $\left(\left[\mathrm{FeO}_{\text {total }} /\right.\right.$ $\left.\mathrm{FeO}_{\text {total }}+\mathrm{MgO}\right] \cdot 100$ ), an oxidation index ("ox" expressed as $\mathrm{Fe}_{2} \mathrm{O}_{3}$. $\left.100 / \mathrm{Fe}_{2} \mathrm{O}_{3 \mathrm{~T}}\right)$, and the $\mathrm{Mg}$ number $(\mathrm{Mg} \#=\mathrm{MgO} / \mathrm{MgO}+\mathrm{FeO}$ calculated $90 \%$ of total iron as $\mathrm{FeO}$ ) (Table 1). The results of the quantitative phase analysis are given in Table 5. The analytical error of the determination is calculated with $\pm 10 \%$.

\section{RESULTS AND DISCUSSION}

\section{Mineralogical Effects of Alteration}

Of the $379 \mathrm{~m}$ drilled during Leg 140, $56.86 \mathrm{~m}$ of core was recovered, or about $13 \%$ of the drilled section. The rocks are aphyric to moderately phyric plagioclase-pyroxene-olivine diabases that are all mineralogically and chemically altered to some extent. The degree of alteration, defined as the abundance of secondary minerals, was visually estimated in thin section (Table 1). Alteration was also estimated in shipboard thin sections that were point counted for alteration phases to ascertain the reliability of the visual estimates. The visual estimates agree within $5 \%-10 \%$ of the estimates from shipboard point counts. Even the least altered dark gray samples are affected by a pervasive background alteration of about $10 \%-20 \%$. The light gray rocks exhibiting more intensive background alteration are $20 \%-70 \%$ recrystallized. The light gray to greenish halos around veins and the alteration patches are generally more than $50 \%$ altered and range up to $90 \%$ altered.

Amphibole, chlorite, and albite are ubiquitous secondary minerals replacing primary minerals and interstitial material. The amphiboles are mainly actinolitic hornblende to magnesiohornblende, but also range to actinolite and local edenitic hornblende (Alt et al., this volume; Laverne et al., this volume). Actinolitic amphibole, plus finegrained magnetite (a few microns), partly replaces clinopyroxene and interstitial material and is the most abundant alteration phase in all rocks. Olivine is commonly replaced by chlorite, chlorite + quartz, mixed-layer chlorite-smectite, actinolitic amphibole, or by talc and magnetite in some slightly altered samples. Plagioclase is partly replaced by albite, oligoclase, and minor laumontite, prehnite, and anhydrite in irregular patches and veins, and the outer rims of plagioclase in patches and halos are commonly replaced by secondary anorthite (Laverne et al., this volume). Titanite usually occurs as tiny crystals in interstitial areas or together with ilmenite replacing igneous titanomagnetite. The highly altered alteration patches often contain irregular amygdules, $0.01-10 \mathrm{~mm}$ across, that are filled with actinolite, chlorite, epidote, quartz, laumontite, and prehnite. Patches also contain greater amounts of prehnite and anhydrite than do the dark gray host rocks.

The quantitative analysis of mineral abundances in whole rocks by XRD shows that plagioclase and clinopyroxene contents decrease with increasing alteration, whereas the amphibole content increases (Fig. 3). In some samples talc and quartz were also detected. Figure 4 shows, in detail, that the dark gray host rocks contain higher contents of plagioclase and clinopyroxene than are in the associated alteration patch or halo portion. In comparison, the amphibole content, mainly actinolite, increases by a factor of two to three.

Veins are common throughout the core, and mainly consist of amphibole, chlorite, or a combination of these minerals. Later veins of epidote or epidote + quartz cut across the actinolite veins, and anhydrite and zeolites are interpreted to be the last alteration products (Shipboard Scientific Party, 1992). Local secondary clinopyroxene, plus hornblende and calcic secondary plagioclase, indicate early hightemperature $\left(400^{\circ}-500^{\circ} \mathrm{C}\right)$ hydrothermal alteration. This was followed by alteration at varying (lower) temperatures and fluid compositions, which produced the varying amphibole compositions and greenschist minerals, which are followed by zeolites and prehnite at the lowest temperatures (Laverne et al., this volume). The presence of talc replacing olivine, and relict olivine mark intervals where water/rock ratios

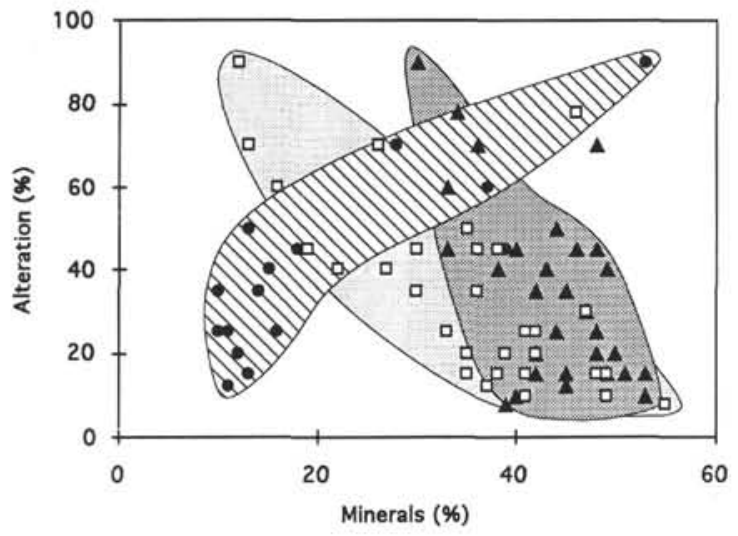

Figure 3. Degree of alteration vs. plagioclase, clinopyroxene, and amphibole content. Solid circles = amphibole; solid triangles = plagioclase; open squares = clinopyroxene.

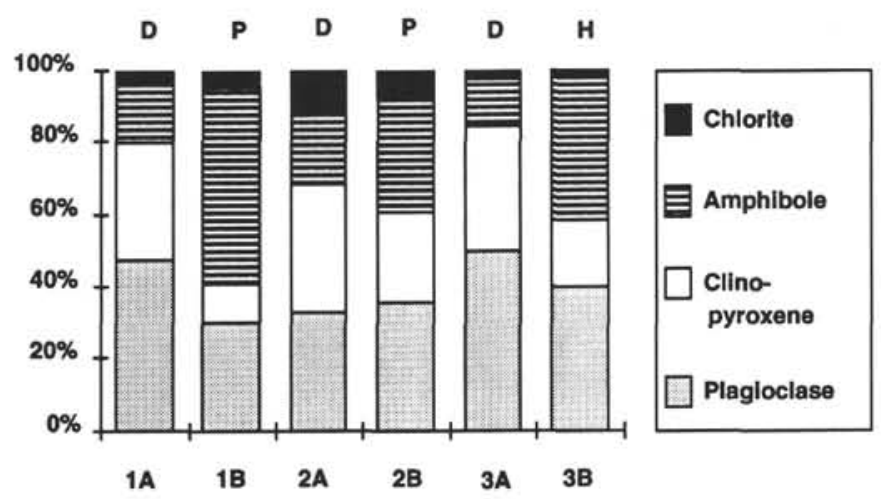

Figure 4. Mineral composition of three samples, separated in halo- $(\mathrm{H})$ or patch- $(\mathrm{P})$ rich parts and surrounding host rocks (D). Key to samples: $1 \mathrm{~A}=$ 140-504B-187R-1, 59-63 cm A; 1B = 140-504B-187R-1, 59-63 cm B; $2 \mathrm{~A}=$ 140-504B-222R-1, 115-120 cm A; 2B = 140-504B-222R-1, 115-120 cm B; $3 \mathrm{~A}=140-504 \mathrm{~B}-235 \mathrm{R}-1,21-24 \mathrm{~cm} \mathrm{~A} ; 3 \mathrm{~B}=140-504 \mathrm{~B}-235 \mathrm{R}-1,21-24 \mathrm{~cm} \mathrm{~B}$.

were low and alteration effects are minimal (e.g., 1700-1750 mbsf; Shipboard Scientific Party, 1992).

\section{Primary Chemical Variations}

In general the major element data of crustal rocks cored during Leg 140 exhibit a relatively uniform chemical composition, as seen in the previously drilled sections above 1621 mbsf (Emmermann, 1985; Hubberten et al., 1983). The samples studied in the present work represent moderately evolved mid-ocean-ridge basalts with relatively high $\mathrm{MgO}$ contents between 7.9 and $10 \mathrm{wt} \%$ and $\mathrm{Mg}$ numbers between 0.60 and 0.70 . According to their normative mineralogy, the diabases are classified as olivine to slightly quartz normative tholeiites. However, the rocks are unusually low in incompatible elements $\left(\mathrm{TiO}_{2}=0.42-1.1 \mathrm{wt} \%, \mathrm{Zr}=23-62 \mathrm{ppm}\right)$.

Despite the relative uniform composition of the rocks, some variations in the "fresh" rocks occur. $\mathrm{Cr}, \mathrm{Ni}, \mathrm{Sr}$, and $\mathrm{CaO} / \mathrm{CaO}+\mathrm{Na}_{2} \mathrm{O}$ are positively correlated with $\mathrm{Mg}$ number, whereas $\mathrm{SiO}_{2}, \mathrm{TiO}_{2}, \mathrm{Y}$, and $\mathrm{Zr}$ exhibit negative correlations with $\mathrm{Mg}$ number, reflecting varying degrees of differentiation (Autio et al., 1989), and perhaps some accumulation of olivine and plagioclase in the rocks. Some significant variations in compositions of "fresh" rocks apparently occur over vertical intervals in the core. Mg numbers (and the corresponding elements and oxides above) are relatively high in the interval from 1704 to $1734 \mathrm{mbsf}$, at about $1925 \mathrm{mbsf}$, and possibly from 1790 to $1830 \mathrm{mbsf}$, whereas $\mathrm{TiO}_{2}, \mathrm{Zr}$, and $\mathrm{Y}$ are low in these zones (Fig. 5 and 


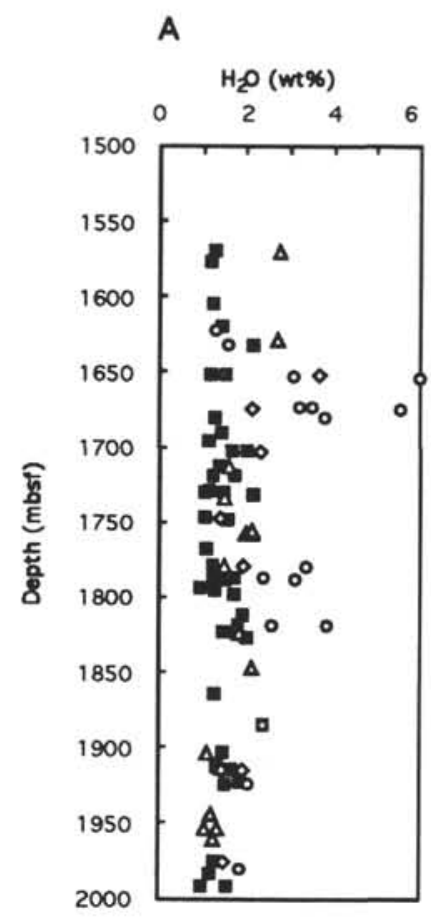

B

C

D

$\mathbf{E}$

\begin{tabular}{llllllllll} 
& Zn (ppm) & \multicolumn{1}{c}{ Cu (ppm) } \\
20 & 40 & 60 & 80 & 100 & 0 & 50 & 100 & 150 & 200
\end{tabular}

$\begin{array}{lll}\mathrm{TlO}_{\mathrm{Z}} \text { (wt\%) } \\ 0.5 \quad 1.0 & 1.5 \quad 1\end{array}$

$\mathrm{CaO}(w \mathrm{t} \%)$
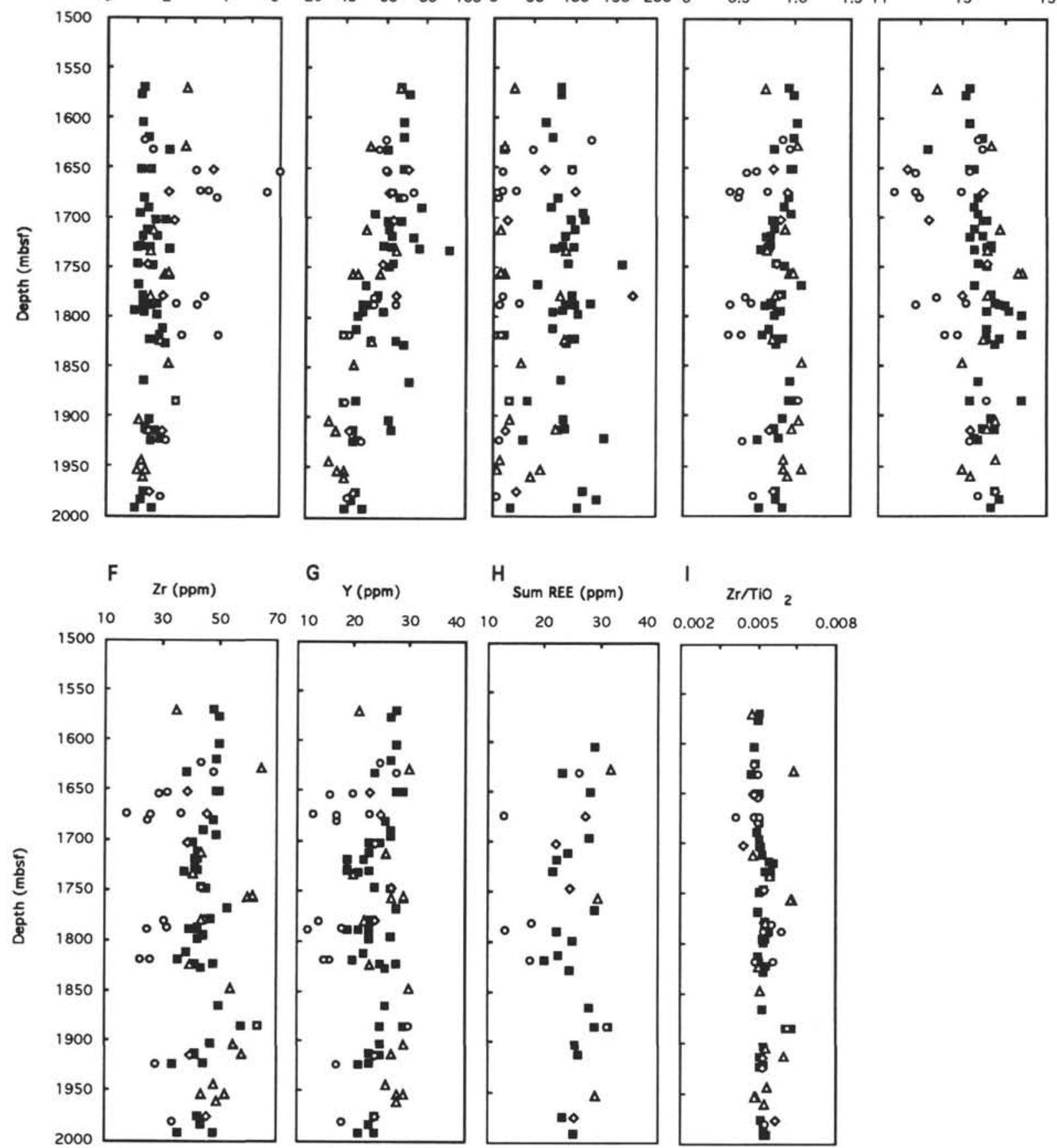

$\mathrm{H}_{\text {SUT REE (ppm) }} \mathrm{I} \mathrm{zr} / \mathrm{TiO} \mathrm{O}_{2}$

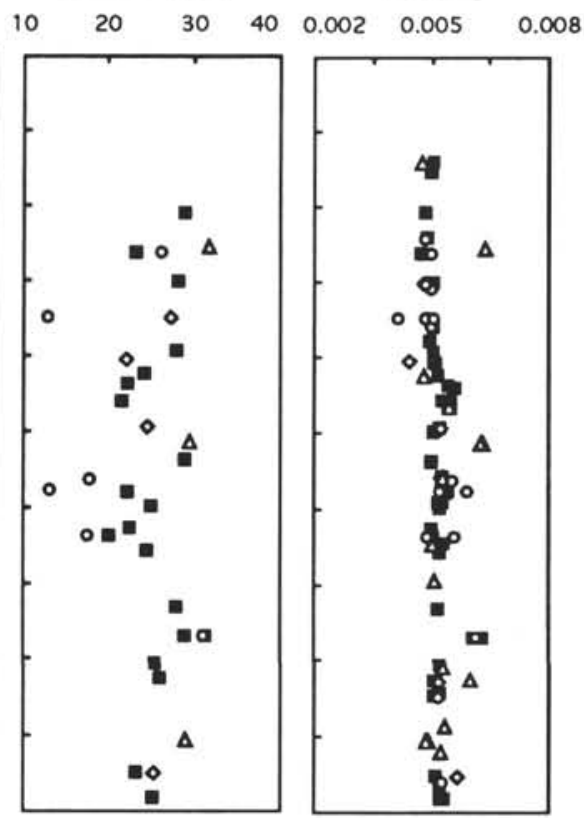

Figure 5. Downhole variations of Leg 140 diabases. Solid square = macroscopically dark, less altered diabases; open triangle = macroscopically light, high background alteration; open diamond $=$ alteration halos around veins; open circle $=$ green to gray alteration patches .

Table 1). Minima in Mg number (and corresponding elements and oxides) occur at 1850 and 1950 mbsf, coinciding with maxima in $\mathrm{TiO}_{2}, \mathrm{Zr}$, and $\mathrm{Y}$ contents. Because only $62 \%$ of the recovered units is represented by this data set, some of these variations could be attributed to a lack of sufficient data over certain intervals (e.g., at 1850 mbsf; Fig. 5). Combining the 79 shipboard chemical analyses to these plots adds to the scatter, but does not eliminate these general variations with depth. Such vertical variations may be related to intrusion of dikes in packets, whereby several dikes with similar compositions are intruded close together over a relatively short time span. System- atic intrusion of such packets would give rise to compositional variations on a scale larger than an individual dike, whereas intrusion of dikes from a different magma batch into a previous packet could give rise to scatter in such larger-scale variations.

The highly altered "patches" show obvious depletions in $\mathrm{TiO}_{2}$, $\mathrm{CaO}, \mathrm{Y}, \mathrm{Zr}$, and total REE values compared to less altered rocks (Fig. 5D-H), and are particularly noticeable in three different zones at 1650-1700 mbsf, 1780-1830 mbsf, and around $1920 \mathrm{mbsf}$ (Fig. 5A). Despite depletion of the patches in $\mathrm{TiO}_{2}$ and $\mathrm{Zr}$, the patches have $\mathrm{Zr} / \mathrm{TiO}_{2}$ ratios identical to the mean value 0.0051 for the section, and 


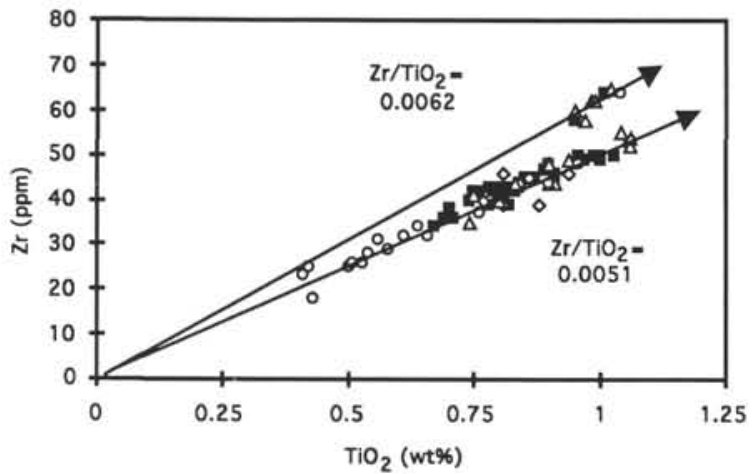

Figure $6 . \mathrm{Zr}$ vs. $\mathrm{TiO}_{2}$ of Leg 140 diabases. Refer to Figure 5 for explanation of symbols.

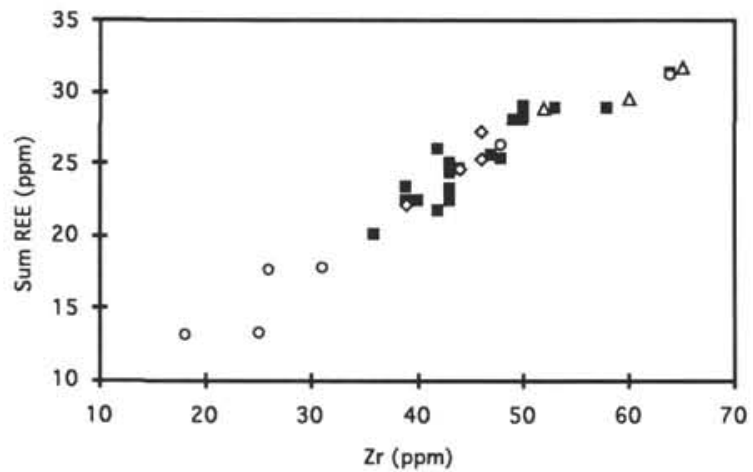

Figure 7. Total REE vs. Zr of selected Leg 140 diabases. Refer to Figure 5 for explanation of symbols.

it is only samples other than the patches that devir*a significantly from the mean value of 0.0051 (Fig. 5I). Besides elc ated $\mathrm{Zr} / \mathrm{TiO}_{2}$ (Fig. 6), the deviant samples are also enriched in $\mathrm{Zr}$ relative to total REE (Fig. 7), suggesting that they represent a second magmatic trend. Data for rocks recovered from all legs at Hole 504B show that the small group of samples with a $\mathrm{Zr} / \mathrm{TiO}_{2}$ ratio of 0.0062 fall within the range of the vast majority of rocks recovered from the rest of the hole (Fig. 8). Only a few units of enriched or transitional basalts with $\mathrm{Zr} / \mathrm{TiO}_{2}$ greater than 0.007 occur from sections drilled during Legs 70 and 83 sections (Autio and Rhodes, 1983; Emmermann, 1985).

The REE distribution patterns of Leg 140 whole rock samples (Fig. 9) are similar to those of samples from shallower in Hole 504B. Samples with varying percentages of alteration and alteration halos around veins generally show no significant differences from "fresh" rocks (Fig. 9), and total REE contents of the rocks vary between 21 and $32 \mathrm{ppm}$ (Table 5). In contrast, the centimeter-size alteration patches have significantly lower REE contents, 13 to $18 \mathrm{ppm}$, and show strong positive Eu-anomalies (Fig. 10). Total REE contents show strong positive correlations with some indices of differentiation $\left(\mathrm{Zr}, \mathrm{Y}, \mathrm{TiO}_{2}\right.$, and $\mathrm{P}_{2} \mathrm{O}_{5}$ ), but exhibit no correlation with other differentiation indicators (e.g., $\mathrm{Mg}$ number, $\mathrm{SiO}_{2}, \mathrm{Sr}$, and $\mathrm{CaO} / \mathrm{CaO}+\mathrm{Na}_{2} \mathrm{O}$ ). The patches generally contain 2-20 volume percent (vol\%) amygdules filled with secondary minerals, but dilution of igneous REE contents by REE-poor secondary minerals filling primary pore space cannot account for the $50 \%$ depletions of REE (and other trace elements) observed in many of the patches.

One possibility for these trace and minor element variations is that they represent the effects of hydrothermal alteration, with leaching of $\mathrm{REE}, \mathrm{Zr}, \mathrm{Y}, \mathrm{Ti}$, and $\mathrm{P}$ by hydrothermal fluids. The patches in Leg 140 rocks generally contain 2-20 vol\% amygdules surrounded by a halo of intensively altered host rock. The high degree of alteration of the host

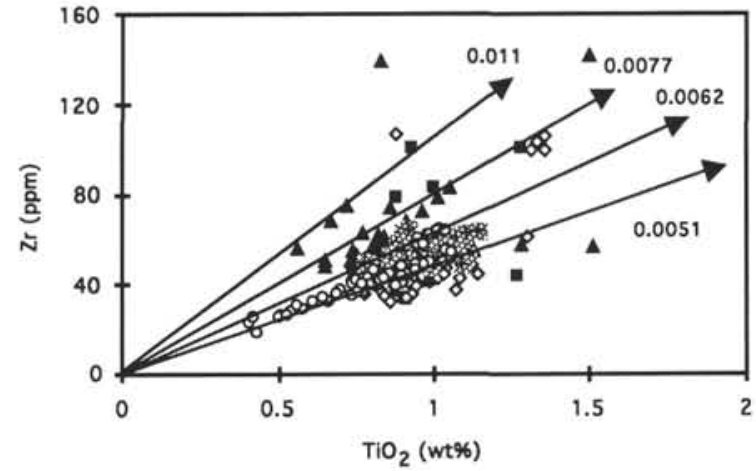

Figure $8 . \mathrm{Zr}$ vs. $\mathrm{TiO}_{2}$ of $\mathrm{Leg} 69,70,83,111$, and 140 samples. Solid square $=$ Leg 69, (Hubberten et al., 1983); open diamond = Leg 70, (Hubberten et al., 1983); solid triangle $=$ Leg 83, (Emmermann, 1985); cross $=$ Leg 111, (Naujoks, 1990); open circle $=$ Leg 140, this study.

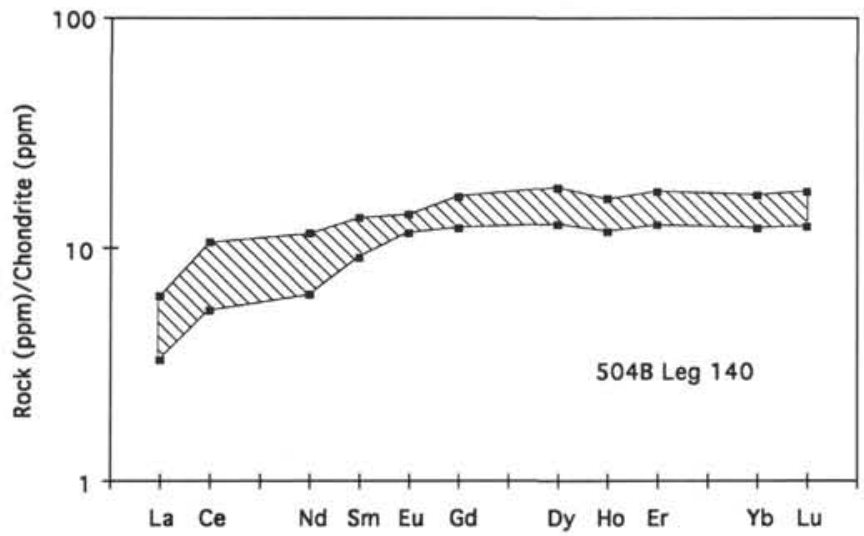

Figure 9. Chondrite-normalized rare earth element distribution (REE) of Leg 140 whole-rock samples with different amounts of alteration (Chondrite values: Evensen et al., 1978).

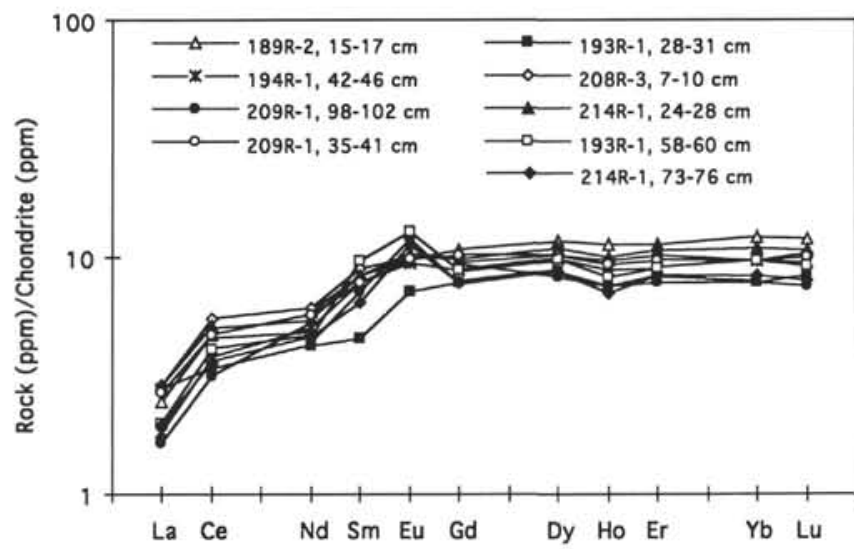

Figure 10. Chondrite-normalized rare earth element distribution (REE) of patch-rich samples of Leg 140 (Chondrite values: Evensen et al., 1978).

rock is attributed to greater primary pore space, which, when filled with hydrothermal fluids, facilitated recrystallization of the rock. Ti, $\mathrm{Y}$, and total REE contents exhibit increased scatter to low values at high degrees of alteration (Fig. 11), consistent with the hypothesis of leaching of these elements during hydrothermal alteration. $\mathrm{Zr}$ and $\mathrm{P}$ contents exhibit scatter to both low and high values at increasing 
A
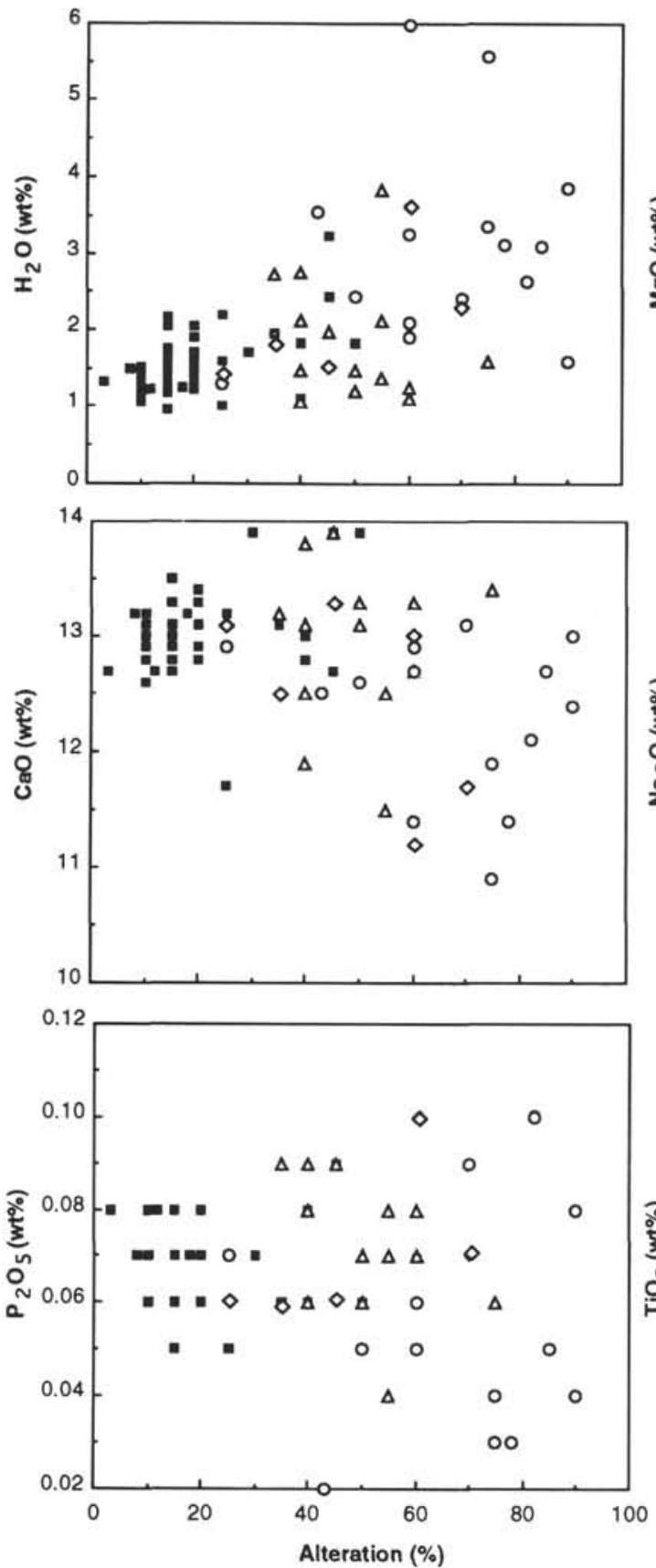
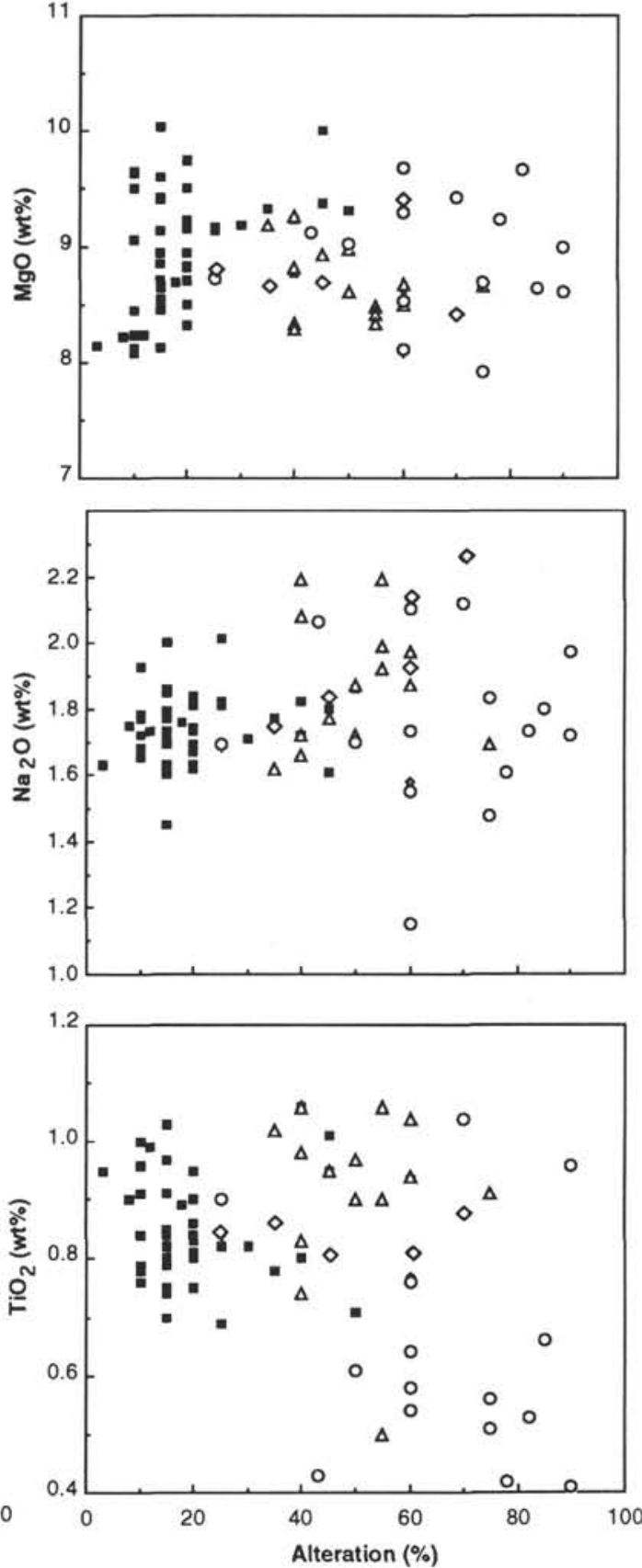

Figure 11. Major element oxides (wt \%) (A) and trace elements (ppm) (B) vs. percentage of alteration for Leg 140 rocks. Symbols as in Figure 5. Arrows indicate samples that plot off scale.

intensity of alteration (Fig. 11); however, both losses and gains of these elements suggest that hydrothermal alteration processes must be more complicated. At similar degrees of alteration, the alteration halos do not exhibit the losses of REE, Y, $\mathrm{Zr}, \mathrm{Ti}$, and $\mathrm{P}$ that are seen in the alteration patches (Fig. 11), suggesting either that different alteration processes occurred in patches and halos, or that hydrothermal alteration may not be responsible for the trace element depletions in the patches. The secondary mineralogy of patches and halos is generally similar (Shipboard Scientific Party, 1992; Alt et al., this volume; Laverne et al., this volume), indicating that alteration processes did not differ significantly between these two portions of the rocks. Moreover, alteration halos bordering veins would seem to be sites of more efficient leaching of elements, which could be removed by solutions circulating in the vein. In contrast, leaching of elements from the alteration patches appears more difficult, because they are isolated from circulating solutions and the only means of removal of elements would be by diffusion through intergranular porosity and permeability. Although some of the chemical changes occurring in the alteration patches are probably due to hydrothermal alteration, it appears unlikely that all of the trace and minor element depletions exhibited by many of the alteration patches are the results of hydrothermal alteration (particularly $\mathrm{Ti}, \mathrm{Zr}, \mathrm{Y}$, and REE, which are generally considered to be immobile; Pearce and Norry, 1979; Gillis et al., 1992).

Another possible explanation for this feature is that the patches originally had a smaller proportion of highly differentiated, late-stage 
B
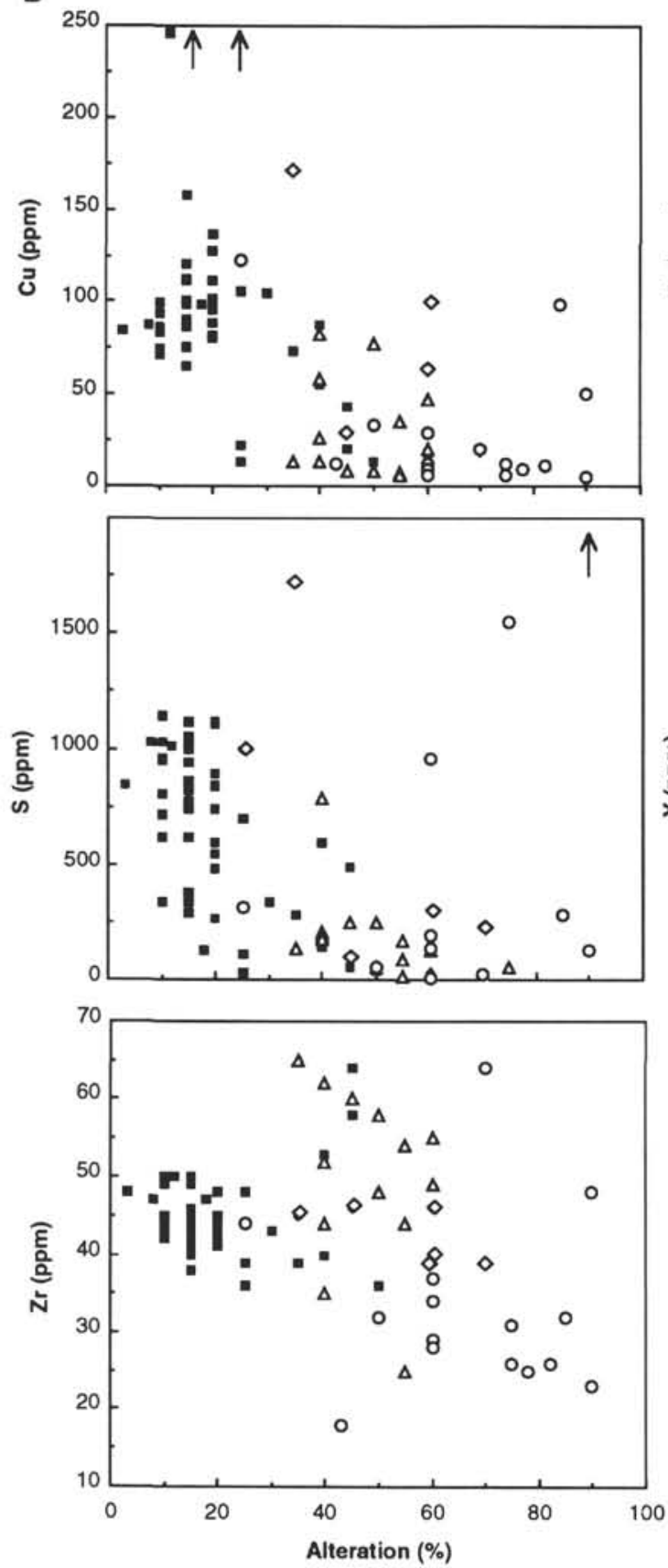
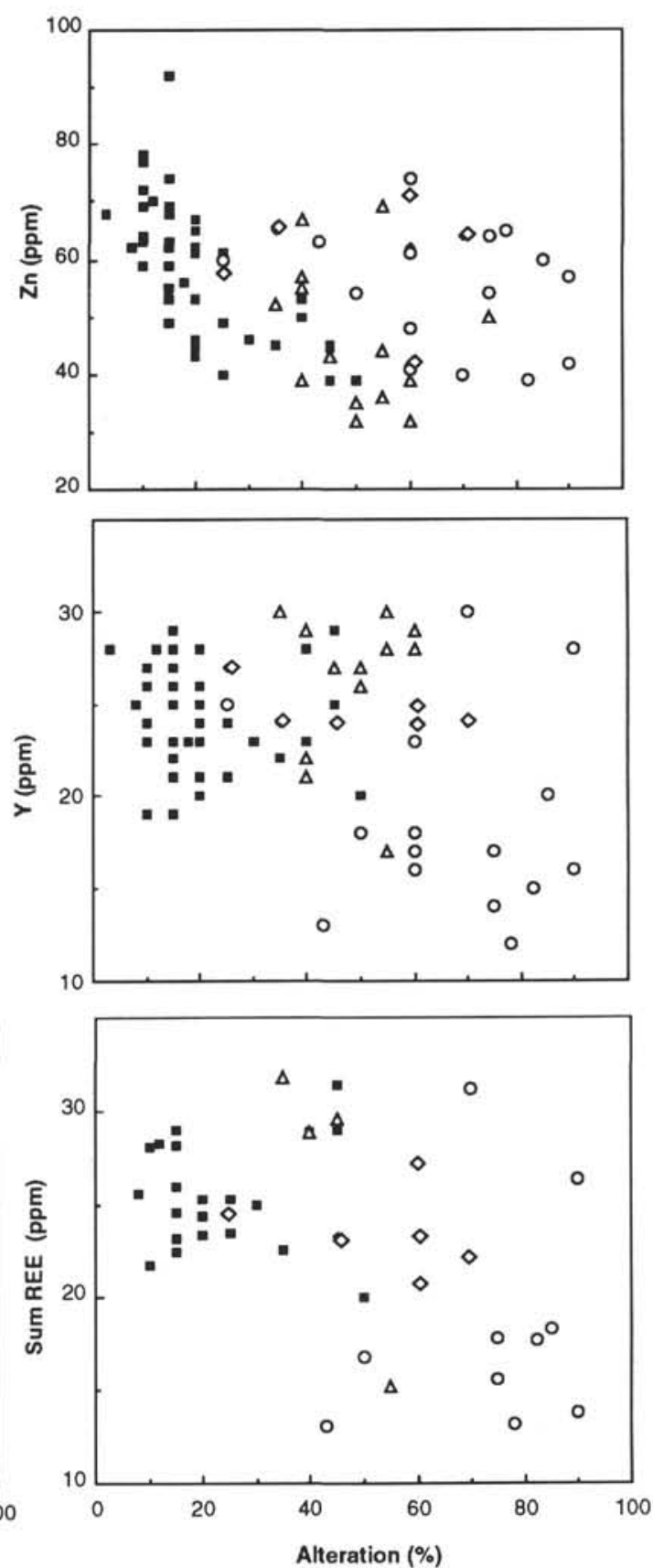

Figure 11 (continued).

magmatic liquids trapped than the surrounding rock had. Such latestage magmatic liquids are described by the Shipboard Scientific Party (1992) as interstitial pockets of granophyric intergrowths of quartz + albite, with minor pyroxene, apatite, and Fe-Ti oxides, and sulfide mineral inclusions. These are known to be strongly enriched in incompatible elements, showing a negative Eu-anomaly. The quantitative XRD phase analysis indicates that quartz occurs in fresh samples only, consistent with occurrence of these pockets only in the patch-free rocks. The round to irregularly shaped amygdules may represent gas $\left(\mathrm{CO}_{2}\right)$ exsolution in some cases, but are more likely diktytaxitic vugs, produced by shrinkage during crystallization and cooling of the melt. Exclusion of the late-stage highly differentiated interstitial melt may in some way be related to formation of these vugs, perhaps as the result of exclusion by a $\mathrm{CO}_{2}$-rich volatile phase.
These portions of rocks have a higher permeability due to the high percentage of vugs, leading to more intense recrystallization during hydrothermal alteration. The observed positive Eu-anomalies in the patches are likely caused by the extensive recrystallization of plagioclase, which typically exhibits strong positive Eu-anomalies.

Similar intensively altered patches occur in the upper dike sections in Hole 504B, and the same types of chemical changes have been described in those samples (Alt and Emmermann, 1985; Alt et al., 1989). The chemical differences between the patches and the host rocks were simply attributed to hydrothermal alteration in those studies, but after further evaluation, we think that the main depletion of $\mathrm{Ti}, \mathrm{Zr}, \mathrm{Y}$, and REE in these zones is a primary igneous effect, although certainly some chemical changes occurred during hydrothermal alteration (see below). 


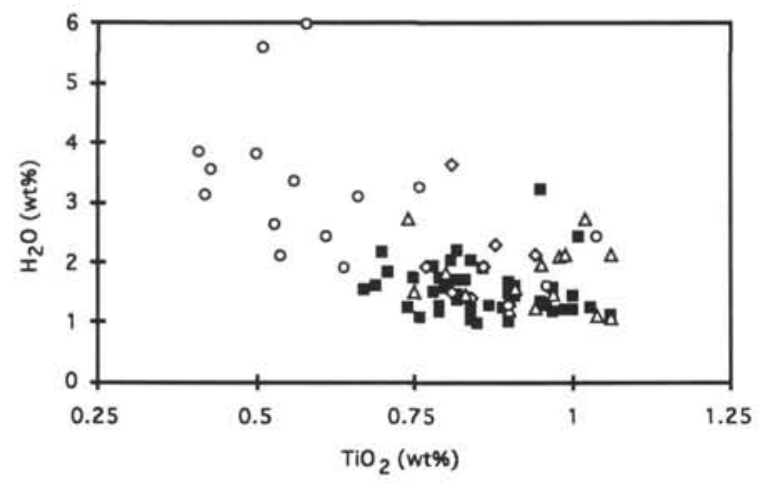

Figure 12. $\mathrm{H}_{2} \mathrm{O}^{+}$vs. $\mathrm{TiO}_{2}$ of Leg 140 diabases. Refer to Figure 5 for explanation of symbols.

\section{Chemical Effects of Hydrothermal Alteration}

Despite the presence of magmatic variations in composition, plots of element and oxide concentrations vs. depth and percentage of alteration reveal the effects of hydrothermal alteration in Leg 140 rocks (Figs. 5, 11, and 12). $\mathrm{H}_{2} \mathrm{O}^{+}$contents exhibit a general trend to increasing values at greater degrees of alteration. The $\mathrm{H}_{2} \mathrm{O}^{+}$contents of the fresh samples are between 1 and $2 \mathrm{wt} \%$, whereas the more altered samples contain up to $6 \mathrm{wt} \%$ water. The samples with more than $2 \mathrm{wt} \% \mathrm{H}_{2} \mathrm{O}^{+}$are mainly alteration patches, and occur in three different zones located between 1650 and 1700,1780 and 1830 , and around 1920 mbsf (Fig. 5A). These three zones correlate with maxima in the abundance of alteration patches logged in the recovered core, and are characterized by maxima of porosity and natural remanent magnetization (NRM) inclination, and by minima of bulk density and velocity (Scientific Shipboard Party, 1992).

The rocks do not exhibit any increase in $\mathrm{MgO}$ with increasing alteration (Fig. 11), as is predicted from experimental seawater-basalt reactions at temperatures of $250^{\circ}-350^{\circ} \mathrm{C}$ (e.g., Seyfried, 1987). The general lack of $\mathrm{Mg}$ uptake by the rocks is consistent with low seawater/rock ratios, and may be attributed at least in part to loss of $\mathrm{Mg}$ from circulating fluids during prior reaction with rock in the shallower portions of the hydrothermal system. Many patches, halos, and more intensively altered rocks exhibit trends toward losses of $\mathrm{CaO}$ and gains of $\mathrm{Na}_{2} \mathrm{O}$ as the result of alteration of primary plagioclase to albite and oligoclase. Other patches have lost $\mathrm{CaO}$ with no $\mathrm{Na}_{2} \mathrm{O}$ gain, and one sample has lost both $\mathrm{CaO}$ and $\mathrm{Na}_{2} \mathrm{O}$. The latter reflects the abundance of chlorite and extensive alteration of both pyroxene and plagioclase in the sample. Despite trends of $\mathrm{P}_{2} \mathrm{O}_{5}$ depletion that are attributed to igneous variations (see above), $\mathrm{P}_{2} \mathrm{O}_{5}$ contents exhibit increased scatter to both high and low values at high degrees of alteration (Fig. 11), consistent with mobility of $\mathrm{P}$ and the presence of traces of secondary apatite in the rocks (Laverne et al., this volume; J. Alt, unpubl. data). The apparent $\mathrm{TiO}_{2}$ losses at high degrees of alteration (Fig. 11) are mainly attributed to primary igneous depletions in the patches, but some loss or local mobility of $\mathrm{Ti}$ is probable in the more highly altered samples, given the intensive alteration of titanomagnetite to titanite in these samples.

$\mathrm{Zn}$ contents decrease progressively with depth starting from 1650 mbsf (Fig. 5B). This is attributed to breakdown of clinopyroxene to amphibole and loss of $\mathrm{Zn}$, which was originally contained in pyroxene, to hydrothermal fluids. This effect is also seen as a general decrease of $\mathrm{Zn}$ contents with increasing alteration in the "fresh" dark gray samples, with no significant further decrease in $\mathrm{Zn}$ contents in the more highly altered patches (Fig. 11). The most altered samples (halos and patches) generally show a strong depletion of $\mathrm{Cu}(<20$ $\mathrm{ppm}$ ), compared with the mean value of the least altered samples (including the host rocks for patches and halos), which is around 90 ppm (Figs. 5C, 11). Samples depleted in Cu contain only traces of sulfide minerals, reflecting a leaching of metals $(\mathrm{Cu})$ and sulfides from the rocks by hydrothermal fluids and leading to generally low $\mathrm{S}$ contents (Fig. 11). Despite loss of metal sulfides from the rocks, many of the low-Cu patches have high $\mathrm{S}$ contents because of the later formation of secondary anhydrite in small veinlets and replacement by plagioclase in the rocks during seawater recharge.

The rocks recovered from the lower sheeted dike complex of Hole $504 \mathrm{~B}$ on Leg 140 are distinguished from the overlying dikes by losses of metals and sulfur from the rocks, by greater proportions of amphibole, and the presence of hornblende and secondary anorthite in addition to actinolite and albite, vs. mainly actinolite and albite in the upper dikes. The secondary mineralogy, as well as oxygen isotope ratios, indicates higher temperatures of hydrothermal alteration in the lower dikes (Laverne et al., this volume; Alt et al., this volume). This led to a more intensive recrystallization of the rocks and losses of metals and sulfur, which are more soluble in hydrothermal fluids at temperatures above $350^{\circ} \mathrm{C}$ (Seyfried, 1987; Seewald and Seyfried, 1990). These effects are similar to those observed in the lower sheeted dikes in ophiolites (Baragar et al., 1990; Alt, unpubl. data). If $40 \mathrm{ppm}$ $\mathrm{Zn}$ and $50 \mathrm{ppm} \mathrm{Cu}$ are lost from $500 \mathrm{~m}$ of lower dikes, these losses can account for the $\mathrm{Zn}$ and $\mathrm{Cu}$ enrichments observed in the sulfide mineralization in the transition zone in Hole 504B (mean values of 165 and 150 ppm, respectively; Alt et al., 1986). The lower sheeted dikes in the ocean crust are thus likely a major source for metals and sulfur, which are transported by hydrothermal fluids to vents at the seafloor and form sulfide deposits on and within the seafloor.

\section{SUMMARY AND CONCLUSIONS}

Rocks from the lower sheeted dike complex in Hole 504B sampled during Leg 140 are relatively uniform in composition and similar to rocks from the shallower portions of the sheeted dike section of the hole. They are moderately evolved MORB with relatively high $\mathrm{MgO}$ contents (7.9-10 wt\%) and $\mathrm{Mg}$ numbers $(0.60-0.70)$, and have unusually low incompatible element contents $\left(\mathrm{TiO}_{2}=0.42-1.1 \mathrm{wt} \%, \mathrm{Zr}\right.$ $=23-62 \mathrm{ppm})$. The rocks exhibit some compositional variations, however, reflecting varying degrees of differentiation, and olivine and plagioclase accumulation in the rocks. Discrete compositional intervals in the hole may be related to injection of packets of dikes with similar compositions. Systematic depletions of total REE, Zr, Y, $\mathrm{TiO}_{2}$, and $\mathrm{P}_{2} \mathrm{O}_{5}$ in centimeter-size alteration patches are most likely attributed to a lack of highly differentiated late-stage interstitial liquids, rich in incompatible elements, from small portions of the rocks, and are probably related to the formation of diktytaxitic vugs during cooling and crystallization. These vugs enhanced the porosity of the rocks, leading to the extensively altered patches surrounding the vugs and further chemical differences from the host rocks.

All of the Leg 140 rocks are affected by a pervasive background alteration, and are $2 \%-20 \%$ recrystallized. More intensive alteration (up to $80 \%-100 \%$ ) occurred where fluids had greater access to the rocks (i.e., in alteration halos around veins and in isolated alteration patches). As a result of hydrothermal alteration and formation of secondary hydrous phases, the rocks exhibit increased $\mathrm{H}_{2} \mathrm{O}^{+}$. Local gains of $\mathrm{Na}_{2} \mathrm{O}$ and losses of $\mathrm{CaO}$ are related to replacement of primary plagioclase by albite and oligoclase, although secondary anorthite is also present. Slight positive Eu anomalies in more altered samples are attributed to the formation of secondary plagioclase. Some mobility of $\mathrm{P}_{2} \mathrm{O}_{5}$ led to minor increases and decreases in $\mathrm{P}_{2} \mathrm{O}_{5}$ contents. Although most variations in $\mathrm{TiO}_{2}$ are probably related to igneous processes, some mobility of Ti may have occurred locally as the result of intensive alteration of titanomagnetite to titanite. Higher temperatures of alteration in the lower sheeted dikes led to the breakdown of pyroxene and sulfide minerals and losses of $\mathrm{Zn}, \mathrm{Cu}$, and $\mathrm{S}$ to hydrothermal fluids. Later addition of anhydrite to the rocks in microfractures and replacing plagioclase caused local increases in sulfur. The lower sheeted dikes are a major source of metals to hydrothermal fluids for the formation of metal sulfide deposits on and within the seafloor. 


\section{ACKNOWLEDGMENTS}

The authors wish to thank W. Bach for his numerous helpful discussion and his critical review. We also wish to thank the reviewers J.E. Dixon and P.T. Robinson for their critical and helpful contributions. We also are very grateful to M. Keßler and R. Zier for their assistance in performing the chemical analysis. M. Grünhäuser did the XRF measurements, T. Umsonst the XRD measurements, and S. Schmidt helped perform the $\mathrm{S}, \mathrm{H}_{2} \mathrm{O}$, and REE analysis. The research was supported by the Deutsche Forschungsgemeinschaft, Bonn-Bad Godesberg, Federal Republic of Germany (Er 123/6-1+2), and by a grant from JOI-USSAC.

\section{REFERENCES}

Alt, J.C., Anderson, T.F., Bonnell, L., and Muehlenbachs, K., 1989. Mineralogy, chemistry, and stable isotopic compositions of hydrothermally altered sheeted dikes: ODP Hole 504B, Leg 111. In Becker, K., Sakai, H., et al., Proc. ODP, Sci. Results, 111: College Station, TX (Ocean Drilling Program), 27-40.

Alt, J.C., and Emmermann, R., 1985. Geochemistry of hydrothermally altered basalts: Deep Sea Drilling Project Hole 504B. In Anderson, R.N., Honnorez, J., Becker, K., et al., Init. Repts. DSDP, 83: Washington (U.S. Govt. Printing Office), 249-262.

Alt, J.C., Honnorez, J., Laverne, C., and Emmermann, R., 1986. Hydrothermal alteration of a $1 \mathrm{~km}$ section through the upper oceanic crust, Deep Sea Drilling Project Hole 504B: mineralogy, chemistry, and evolution of seawater-basalt interactions. J. Geophys. Res., 91:10309-10335.

Autio, L.K., and Rhodes, J.M., 1983. Costa Rica Rift Zone basalts: geochemical and experimental data from a possible example of multistage melting. In Cann, J.R., Langseth, M.G., Honnorez, J., Von Herzen, R.P., White, S.M., et al., Init. Repts. DSDP, 69: Washington (U.S. Govt. Printing Office), $729-745$.

Autio, L.K., Sparks, J.W., and Rhodes, J.M., 1989. Geochemistry of Leg 111 basalts: intrusive feeders for highly depleted pillows and flows. In Becker, K., Sakai, H., et al., Proc. ODP, Sci. Results, 111: College Station, TX (Ocean Drilling Program), 3-16.

Baragar, W.R.A., Lambert, M.B., Baglow, N., and Gibson, I.L, 1990. The sheeted dyke zone in the Troodos Ophiolite. In Malpas, J., Moores, E.M., Panayiotou, A., Xenophontos, C. (Eds.), Ophiolites: Oceanic Crustal Analogues, 37-51.

Emmermann, R., 1985. Basement geochemistry, Hole 504B. In Anderson, R.N., Honnorez, J., Becker, K., et al., Init. Repts. DSDP, 83: Washington (U.S. Govt. Printing Office), 183-199.

Emmermann, R., and Lauterjung, J., 1990. Double X-ray analysis of cuttings and rock flour: a powerful tool for rapid and reliable determination of borehole lithostratigraphy. Sci. Drill., 1:269-282.

Evensen, N.M., Hamilton, P.J., and O'Nions, R.K., 1978. Rare-earth abundances on chondritic meteorites. Geochim. Cosmochim. Acta., 42:11991212.
Fox, P.J., and Stroup, J., 1981. The plutonic foundation of the oceanic crust. In Emiliani, C. (Ed.), The Sea (The Oceanic Lithosphere): New York (Wiley), 119-218.

Gillis, K.M., Ludden, J.N., and Smith, A.D., 1992. Mobilization of REE during crustal aging in the Troodos Ophiolite, Cyprus. Chem. Geol., 98:71-86.

Govindaraju, K., 1989. 1989 compilation of working values and sample description for 272 geostandards. Geostand. Newsl., 13:1-113.

Hubberten, H.-W., Emmermann, R., and Puchelt, H., 1983. Geochemistry of basalts from Costa Rica Rift Sites 504 and 505 (Deep Sea Drilling Project Legs 69 and 70). In Cann, J.R., Langseth, M.G., Honnorez, J., Von Herzen, R.P., White, S.M., et al., Init. Repts. DSDP, 69: Washington (U.S. Govt. Printing Office), 791-803.

Natland, J.H., Adamson, A.C., Laverne, C., Melson, W.G., and O'Hearn, T.O., 1983. A compositionally nearly steady-state magma chamber at the Costa Rica Rift: evidence from basalt glass and mineral data, Deep Sea Drilling Project Sites 501, 504, and 505. In Cann, J.R., Langseth, M.G., Honnorez, J., Von Herzen, R.P., White, S.M., et al., Init. Repts. DSDP, 69: Washington (U.S. Govt. Printing Office), 811-858.

Naujoks, F., 1990. Geochemie und hydrothermale Alteration des SheetedDike-Komplexes in DSDP Bohrung 504B am Costa Rica Rift [Dipl. arbeit]. Univ. Giessen.

Pearce, J.A., and Norry, M.J., 1979. Petrogenetic implications of Ti, Zr, Y and Nb variations in volcanic rocks. Contrib. Mineral. Petrol., 69:33-47.

Raitt, R.W., 1963. The crustal rocks. In Hill, M. (Ed.), The Sea: Ideas and Observations on Progress in the Study of the Seas: New York (Wiley-Interscience), 3:85-102.

Seewald, J.S., and Seyfried, W.E., Jr., 1990. The effect of temperature on metal mobility in subseafloor hydrothermal systems: constraints from basalt alteration experiments. Earth Planet. Sci. Lett., 101:388-403.

Seyfried, W.E., Jr., 1987. Experimental and theoretical constraints on hydrothermal alteration processes at mid-ocean ridges. Annu. Rev. Earth Planet. Sci., 15:317-335.

Shipboard Scientific Party, 1988. Site 504: Costa Rica Rift. In Becker, K., Sakai, H., et al., Proc. ODP, Init. Repts., 111: College Station, TX (Ocean Drilling Program), 35-251.

1992. Site 504. In Dick, H.J.B., Erzinger, J., Stokking, L.B., et al., Proc. ODP, Init. Repts., 140: College Station, TX (Ocean Drilling Program), 37-200.

Zuleger, E., and Erzinger, J., 1988. Determination of the REE and Y in silicate materials with ICP-AES. Fresenius' Z. Anal. Chem., 332:140-143.

\footnotetext{
- Abbreviations for names of organizations and publications in ODP reference lists follow the style given in Chemical Abstracts Service Source Index (published by American Chemical Society).
}

Date of initial receipt: 26 April 1993

Date of acceptance: 11 January 1994

Ms 137/140SR-022 
Table 1. Major and trace element composition of Hole 504B diabases, recovered during Legs 137/140.

\begin{tabular}{|c|c|c|c|c|c|c|c|c|c|c|c|c|}
\hline $\begin{array}{l}\text { Leg: } \\
\text { Core-section: } \\
\text { Interval }(\mathrm{cm}): \\
\text { Piece no.: } \\
\text { Depth (mbsf): } \\
\text { Lithologic unit*: } \\
\text { Unit rock name: } \\
\text { Alteration }(\%): \\
\text { Alteration type: }\end{array}$ & $\begin{array}{c}137 \\
137 \text { R01 } \\
54-57 \\
6 \\
1570.5 \\
193 \\
\text { OPC } \\
3 \\
\text { D }\end{array}$ & $\begin{array}{c}137 \\
173 \mathrm{R} 01 \\
73-76 \\
9 \\
1570.7 \\
193 \\
\text { OPC } \\
40 \\
\text { L }\end{array}$ & $\begin{array}{c}137 \\
174 \mathrm{R} 02 \\
23-26 \\
5 \\
1578.0 \\
195 \\
\text { OPC } \\
10 \\
\text { D }\end{array}$ & $\begin{array}{c}137 \\
177 \mathrm{R} 01 \\
48-51 \\
13 \\
1605.0 \\
202 \\
\text { OPC } \\
15 \\
\text { D }\end{array}$ & $\begin{array}{c}137 \\
181 \mathrm{M} 1 \\
6-10 \\
1 \\
1620.5 \\
204 \\
\text { OPC } \\
10 \\
\text { D }\end{array}$ & $\begin{array}{c}137 \\
181 \mathrm{M} 2 \\
95-97 \\
7 \mathrm{~B} \\
1622.8 \\
208 \\
\text { OPC } \\
25 \\
\mathrm{P}\end{array}$ & $\begin{array}{c}137 \\
186 \mathrm{R} 02 \\
30-32 \\
8 \\
1628.1 \\
213 \\
\mathrm{AD} \\
35 \\
\mathrm{~L}\end{array}$ & $\begin{array}{c}140 \\
187 \mathrm{R} 01 \\
59-63 \mathrm{~A} \\
14 \\
1632.6 \\
216 \\
\text { sPCD } \\
25 \\
\text { D }\end{array}$ & $\begin{array}{c}140 \\
187 \mathrm{R} 01 \\
59-63 \mathrm{~B} \\
14 \\
1632.6 \\
216 \\
\text { sPCD } \\
90 \\
\mathrm{P}\end{array}$ & $\begin{array}{c}140 \\
189 \mathrm{R} 01 \\
85-88 \\
19 \\
1651.9 \\
218 \\
\text { mPOCD } \\
12 \\
\text { D }\end{array}$ & $\begin{array}{c}140 \\
189 \mathrm{R} 01 \\
90-94 \mathrm{~A} \\
20 \\
1651.9 \\
218 \\
\mathrm{mPOCD} \\
15 \\
\mathrm{D}\end{array}$ & $\begin{array}{c}140 \\
189 \mathrm{R} 01 \\
90-94 \mathrm{~B} \\
20 \\
1651.9 \\
218 \\
\mathrm{mPOCD} \\
60 \\
\mathrm{H}\end{array}$ \\
\hline $\begin{array}{l}\mathrm{SiO}_{2} \text { (wt\%) } \\
\mathrm{TiO}_{2} \\
\mathrm{Al}_{2} \mathrm{O}_{3} \\
\mathrm{Fe}_{2} \mathrm{O}_{3} \\
\mathrm{FeO} \\
\mathrm{MnO} \\
\mathrm{MgO} \\
\mathrm{CaO} \\
\mathrm{Na}_{2} \mathrm{O} \\
\mathrm{P}_{2} \mathrm{O}_{5} \\
\mathrm{H}_{2} \mathrm{O}^{+}\end{array}$ & $\begin{array}{c}50.1 \\
0.95 \\
14.9 \\
2.79 \\
7.30 \\
0.17 \\
8.14 \\
12.7 \\
1.63 \\
0.08 \\
1.33\end{array}$ & \begin{tabular}{|c|c|}
50.7 \\
0.74 \\
15.5 \\
2.36 \\
7.08 \\
0.16 \\
8.33 \\
11.9 \\
2.19 \\
0.06 \\
2.74
\end{tabular} & \begin{tabular}{c|c|}
50.6 \\
1.00 \\
14.8 \\
2.98 \\
7.40 \\
0.18 \\
8.13 \\
12.6 \\
1.66 \\
0.08 \\
1.21
\end{tabular} & $\begin{array}{c}51.0 \\
1.03 \\
14.8 \\
2.81 \\
7.64 \\
0.18 \\
8.71 \\
12.7 \\
1.73 \\
0.08 \\
1.24\end{array}$ & $\begin{array}{c}49.6 \\
1.00 \\
14.6 \\
2.72 \\
7.54 \\
0.18 \\
8.23 \\
13.0 \\
1.68 \\
0.07 \\
1.43\end{array}$ & \begin{tabular}{|l|l|}
50.7 \\
0.90 \\
14.9 \\
2.27 \\
7.32 \\
0.18 \\
8.72 \\
12.9 \\
1.69 \\
0.07 \\
1.29
\end{tabular} & $\begin{array}{l}47.1 \\
1.02 \\
16.2 \\
2.14 \\
7.16 \\
0.17 \\
9.18 \\
13.2 \\
1.62 \\
0.09 \\
2.73\end{array}$ & $\begin{array}{c}50.4 \\
0.96 \\
15.3 \\
2.41 \\
7.10 \\
0.18 \\
8.61 \\
13.0 \\
1.97 \\
0.08 \\
1.60\end{array}$ & \begin{tabular}{|c|}
50.6 \\
0.82 \\
14.8 \\
2.21 \\
8.18 \\
0.17 \\
8.75 \\
11.7 \\
2.01 \\
0.07 \\
2.19
\end{tabular} & $\begin{array}{c}50.5 \\
0.99 \\
15.1 \\
2.68 \\
7.31 \\
0.18 \\
8.24 \\
12.7 \\
1.73 \\
0.08 \\
1.22\end{array}$ & $\begin{array}{c}50.5 \\
0.97 \\
15.1 \\
2.54 \\
7.34 \\
0.18 \\
8.44 \\
12.8 \\
1.77 \\
0.08 \\
1.56\end{array}$ & $\begin{array}{c}49.9 \\
0.81 \\
15.2 \\
2.00 \\
7.83 \\
0.17 \\
8.63 \\
11.2 \\
2.13 \\
0.07 \\
3.65\end{array}$ \\
\hline Sum & 100.1 & 101.8 & 100.6 & 101.9 & 100.1 & 100.9 & 100.6 & 101.6 & 101.5 & 100.7 & 101.3 & 101.6 \\
\hline $\mathrm{Fe}_{2} \mathrm{O}_{3 \mathrm{~T}}$ & 10.9 & 10.2 & 11.2 & 11.3 & 11.1 & 10.4 & 10.1 & 10.3 & 11.3 & 10.8 & 10.7 & 10.7 \\
\hline $\begin{array}{l}\mathrm{S} \text { (ppm) } \\
\mathrm{Cr} \\
\mathrm{Ni} \\
\mathrm{Cu} \\
\mathrm{Zn} \\
\mathrm{Ga} \\
\mathrm{Sr} \\
\mathrm{Y} \\
\mathrm{Zr}\end{array}$ & $\begin{array}{r}842 \\
243 \\
87 \\
84 \\
68 \\
15 \\
46 \\
28 \\
48\end{array}$ & $\begin{array}{r}191 \\
247 \\
89 \\
26 \\
67 \\
14 \\
54 \\
21 \\
35\end{array}$ & $\begin{array}{r}718 \\
221 \\
85 \\
83 \\
72 \\
14 \\
47 \\
27 \\
50\end{array}$ & $\begin{array}{r}379 \\
178 \\
80 \\
65 \\
69 \\
16 \\
47 \\
28 \\
50\end{array}$ & $\begin{array}{r}334 \\
226 \\
84 \\
74 \\
69 \\
14 \\
45 \\
27 \\
49\end{array}$ & $\begin{array}{r}316 \\
302 \\
92 \\
122 \\
60 \\
15 \\
45 \\
25 \\
44\end{array}$ & $\begin{array}{r}139 \\
348 \\
134 \\
13 \\
52 \\
15 \\
66 \\
30 \\
65\end{array}$ & $\begin{array}{r}131 \\
284 \\
90 \\
50 \\
57 \\
16 \\
51 \\
28 \\
48\end{array}$ & $\begin{array}{r}30 \\
257 \\
94 \\
13 \\
61 \\
15 \\
54 \\
24 \\
39\end{array}$ & $\begin{array}{r}1015 \\
255 \\
88 \\
246 \\
70 \\
14 \\
48 \\
28 \\
50\end{array}$ & $\begin{array}{r}740 \\
278 \\
92 \\
98 \\
69 \\
17 \\
48 \\
29 \\
49\end{array}$ & $\begin{array}{r}308 \\
320 \\
93 \\
63 \\
71 \\
15 \\
54 \\
23 \\
39\end{array}$ \\
\hline $\begin{array}{l}\mathrm{FM} \\
\mathrm{Mg \#} \\
\mathrm{Ox} \\
\mathrm{Y} / \mathrm{Zr} \\
\mathrm{Zr} / \mathrm{TiO}_{2}\end{array}$ & $\begin{array}{l}54.6 \\
0.60 \\
25.6 \\
0.58 \\
0.0051\end{array}$ & $\begin{array}{l}52.5 \\
0.62 \\
23.1 \\
0.60 \\
0.0047\end{array}$ & $\begin{array}{c}55.3 \\
0.59 \\
26.6 \\
0.54 \\
0.0050\end{array}$ & $\begin{array}{c}53.9 \\
0.60 \\
24.9 \\
0.56 \\
0.0049\end{array}$ & $\begin{array}{c}54.8 \\
0.59 \\
24.5 \\
0.55 \\
0.0049\end{array}$ & $\begin{array}{c}51.8 \\
0.62 \\
21.8 \\
0.57 \\
0.0049\end{array}$ & $\begin{array}{c}49.7 \\
0.64 \\
21.2 \\
0.46 \\
0.0064\end{array}$ & $\begin{array}{c}51.8 \\
0.62 \\
23.4 \\
0.58 \\
0.0050\end{array}$ & $\begin{array}{c}53.7 \\
0.61 \\
19.6 \\
0.62 \\
0.0048\end{array}$ & $\begin{array}{c}54.1 \\
0.60 \\
24.8 \\
0.56 \\
0.0051\end{array}$ & $\begin{array}{c}53.3 \\
0.61 \\
23.8 \\
0.59 \\
0.0051\end{array}$ & $\begin{array}{l}52.7 \\
0.62 \\
18.7 \\
0.59 \\
0.0048\end{array}$ \\
\hline
\end{tabular}

Notes: * = Shipboard Scientific Party (1992). $\mathrm{K}_{2} \mathrm{O}<0.05 \% ; \mathrm{CO}_{2}<0.1 \% ; \mathrm{Rb}, \mathrm{Pb}, \mathrm{Th}<5$ ppm; $\mathrm{Ba}<20$ ppm. Unit rock name: $\mathrm{m}=$ moderately; $\mathrm{s}=\mathrm{sparsely} ; \mathrm{O}=\mathrm{O}$ Olivine; $\mathrm{P}=$ plagioclase; $\mathrm{C}=$ clinopyroxene; $\mathrm{D}=$ diabase; $\mathrm{A}=$ aphyric. Alteration type: $\mathrm{D}=$ macroscopically dark, less altered diabase; $\mathrm{L}=$ macroscopically light, high background alteration; $\mathrm{H}=$ diabase containing high percentage of halos around veins; $\mathrm{P}=$ samples with green patches or vugs and a high background alteration. $\mathrm{n} . \mathrm{d} .=$ not determined. $\mathrm{FM}=\mathrm{FeO}$ total $/\left(\mathrm{FeO} \mathrm{total}_{\mathrm{f}}\right.$ $+\mathrm{MgO}) \cdot 100 ; \mathrm{Mg} \#=\mathrm{MgO} / \mathrm{MgO}+\mathrm{FeO}(\mathrm{molar}) ; \mathrm{Ox}=\mathrm{Fe}_{2} \mathrm{O}_{3} \cdot 100 / \mathrm{Fe}_{2} \mathrm{O}_{3 \mathrm{~T}}$

Table 1 (continued).

\begin{tabular}{|c|c|c|c|c|c|c|c|c|c|c|c|c|}
\hline $\begin{array}{l}\text { Leg: } \\
\text { Core-section: } \\
\text { Interval }(\mathrm{cm}) \text { : } \\
\text { Piece no.: } \\
\text { Depth (mbsf): } \\
\text { Lithologic unit*: } \\
\text { Unit rock name: } \\
\text { Alteration }(\%): \\
\text { Alteration type: }\end{array}$ & $\begin{array}{c}140 \\
189 \mathrm{R} 02 \\
15-17 \\
3 \\
1653.5 \\
218 \\
\mathrm{mPOCD} \\
85 \\
\mathrm{P}\end{array}$ & $\begin{array}{c}140 \\
190 \mathrm{R} 01 \\
10-14 \\
2 \\
1655.2 \\
218 \\
\mathrm{mPOCD} \\
60 \\
\text { P }\end{array}$ & $\begin{array}{c}140 \\
193 \mathrm{R} 01 \\
22-24 \\
7 \\
1674.7 \\
220 \\
\mathrm{mPOCD} \\
60 \\
\mathrm{P}\end{array}$ & $\begin{array}{c}140 \\
193 \mathrm{R} 01 \\
28-31 \\
9 \\
1674.8 \\
220 \\
\mathrm{mPOCD} \\
43 \\
\mathrm{P}\end{array}$ & $\begin{array}{c}140 \\
193 \mathrm{R} 01 \\
4446 \\
13 \mathrm{~A} \\
1675.0 \\
220 \\
\mathrm{mPOCD} \\
60 \\
\mathrm{H}\end{array}$ & $\begin{array}{c}140 \\
193 \mathrm{R} 01 \\
58-60 \mathrm{~B} \\
14 \\
1675.1 \\
220 \\
\mathrm{mPOCD} \\
75 \\
\mathrm{P}\end{array}$ & $\begin{array}{c}140 \\
194 \mathrm{R} 01 \\
36-40 \\
7 \\
1680.8 \\
220 \\
\text { mPOCD } \\
20 \\
\text { D }\end{array}$ & $\begin{array}{c}140 \\
194 \mathrm{R} 01 \\
42-46 \\
8 \\
1680.8 \\
220 \\
\mathrm{mPOCD} \\
55 \\
P\end{array}$ & $\begin{array}{c}140 \\
195 \mathrm{R} 01 \\
1-3 \\
1 \\
1690.3 \\
221 \\
\text { mPOCD } \\
10 \\
\text { D }\end{array}$ & $\begin{array}{c}140 \\
196 \mathrm{R} 01 \\
21-26 \\
4 \\
1696.7 \\
222 \\
\text { mPOCD } \\
15 \\
\text { D }\end{array}$ & $\begin{array}{c}140 \\
197 \mathrm{R} 01 \\
29-31 \\
7 \\
1703.1 \\
222 \\
\text { mPOCD } \\
70 \\
\mathrm{H}\end{array}$ & $\begin{array}{c}140 \\
197 \mathrm{R} 01 \\
116-120 \\
26 \\
1704.0 \\
223 \\
\text { sPOCD } \\
20 \\
\text { D }\end{array}$ \\
\hline $\begin{array}{l}\mathrm{SiO}_{2}(w 1 \%) \\
\mathrm{TiO}_{2} \\
\mathrm{Al}_{2} \mathrm{O}_{3} \\
\mathrm{Fe}_{2} \mathrm{O}_{3} \\
\mathrm{FeO} \\
\mathrm{MnO} \\
\mathrm{MgO} \\
\mathrm{CaO} \\
\mathrm{Na}_{2} \mathrm{O} \\
\mathrm{P}_{2} \mathrm{O}_{5} \\
\mathrm{H}_{2} \mathrm{O}^{+}\end{array}$ & $\begin{array}{c}50.5 \\
0.66 \\
15.7 \\
1.67 \\
6.69 \\
0.16 \\
8.64 \\
12.7 \\
1.80 \\
0.05 \\
3.09\end{array}$ & $\begin{array}{c}50.8 \\
0.58 \\
14.4 \\
1.38 \\
7.49 \\
0.16 \\
8.11 \\
11.4 \\
1.15 \\
0.05 \\
5.98\end{array}$ & $\begin{array}{c}50.3 \\
0.76 \\
14.9 \\
2.05 \\
7.87 \\
0.17 \\
8.52 \\
11.4 \\
2.10 \\
0.06 \\
3.25\end{array}$ & $\begin{array}{c}50.5 \\
0.43 \\
15.6 \\
1.80 \\
6.48 \\
0.15 \\
9.12 \\
12.5 \\
2.06 \\
0.02 \\
3.55\end{array}$ & $\begin{array}{c}50.2 \\
0.94 \\
15.4 \\
2.43 \\
6.72 \\
0.19 \\
8.08 \\
13.0 \\
1.93 \\
0.10 \\
2.12\end{array}$ & $\begin{array}{c}50.2 \\
0.51 \\
14.5 \\
1.38 \\
7.04 \\
0.13 \\
7.92 \\
10.9 \\
1.48 \\
0.04 \\
5.57\end{array}$ & $\begin{array}{c}50.0 \\
0.95 \\
15.5 \\
2.80 \\
6.84 \\
0.18 \\
8.32 \\
12.9 \\
1.74 \\
0.08 \\
1.29\end{array}$ & $\begin{array}{c}50.5 \\
0.50 \\
14.8 \\
1.34 \\
7.61 \\
0.16 \\
8.42 \\
11.5 \\
1.99 \\
0.04 \\
3.82\end{array}$ & $\begin{array}{c}50.0 \\
0.91 \\
15.6 \\
2.49 \\
7.03 \\
0.17 \\
8.07 \\
12.8 \\
1.93 \\
0.07 \\
1.45\end{array}$ & $\begin{array}{c}50.5 \\
0.97 \\
15.4 \\
2.88 \\
6.95 \\
0.18 \\
8.12 \\
12.9 \\
1.86 \\
0.08 \\
1.18\end{array}$ & $\begin{array}{c}50.1 \\
0.88 \\
15.2 \\
2.34 \\
7.88 \\
0.17 \\
8.39 \\
11.7 \\
2.26 \\
0.07 \\
2.31\end{array}$ & $\begin{array}{c}48.6 \\
0.81 \\
16.2 \\
2.85 \\
6.25 \\
0.16 \\
9.23 \\
13.1 \\
1.62 \\
0.06 \\
2.04\end{array}$ \\
\hline Sum & 101.7 & 101.5 & 101.4 & 102.2 & 101.1 & 99.7 & 100.6 & 100.7 & 100.5 & 101.0 & 101.3 & 100.9 \\
\hline $\mathrm{Fe}_{2} \mathrm{O}_{3 \mathrm{~T}}$ & 9.1 & 9.7 & 10.8 & 9.0 & 9.9 & 9.2 & 10.4 & 9.8 & 10.3 & 10.6 & 11.1 & 9.8 \\
\hline $\begin{array}{l}\mathrm{S}(\mathrm{ppm}) \\
\mathrm{Cr} \\
\mathrm{Ni} \\
\mathrm{Cu} \\
\mathrm{Zn} \\
\mathrm{Ga} \\
\mathrm{Sr} \\
\mathrm{Y} \\
\mathrm{Zr}\end{array}$ & $\begin{array}{r}282 \\
327 \\
100 \\
98 \\
60 \\
15 \\
55 \\
20 \\
32\end{array}$ & $\begin{array}{r}135 \\
299 \\
92 \\
12 \\
61 \\
13 \\
33 \\
16 \\
29\end{array}$ & $\begin{array}{r}192 \\
252 \\
88 \\
29 \\
74 \\
15 \\
57 \\
23 \\
37\end{array}$ & $\begin{array}{l}\text { n.d. } \\
402 \\
113 \\
12 \\
63 \\
\text { n.d. } \\
51 \\
13 \\
18\end{array}$ & $\begin{array}{l}\text { n.d. } \\
278 \\
97 \\
101 \\
62 \\
\text { n.d } \\
49 \\
25 \\
46\end{array}$ & $\begin{array}{r}1550 \\
393 \\
100 \\
6 \\
64 \\
13 \\
39 \\
17 \\
26\end{array}$ & $\begin{array}{r}1120 \\
313 \\
100 \\
80 \\
67 \\
15 \\
49 \\
26 \\
48\end{array}$ & $\begin{array}{r}170 \\
334 \\
105 \\
7 \\
69 \\
13 \\
49 \\
17 \\
25\end{array}$ & $\begin{array}{r}800 \\
259 \\
87 \\
71 \\
78 \\
16 \\
50 \\
27 \\
45\end{array}$ & $\begin{array}{r}293 \\
249 \\
86 \\
111 \\
55 \\
15 \\
50 \\
27 \\
49\end{array}$ & $\begin{array}{r}231 \\
292 \\
92 \\
18 \\
64 \\
15 \\
57 \\
24 \\
39\end{array}$ & $\begin{array}{r}544 \\
346 \\
138 \\
95 \\
61 \\
13 \\
51 \\
23 \\
41\end{array}$ \\
\hline $\begin{array}{l}\mathrm{FM} \\
\mathrm{Mg \#} \\
\mathrm{Ox} \\
\mathrm{Y} / \mathrm{Zr} \\
\mathrm{Zr} / \mathrm{TiO}_{2}\end{array}$ & $\begin{array}{l}48.7 \\
0.65 \\
18.3 \\
0.63 \\
0.0048\end{array}$ & $\begin{array}{l}51.8 \\
0.62 \\
14.2 \\
0.55 \\
0.0050\end{array}$ & $\begin{array}{c}53.3 \\
0.61 \\
19.0 \\
0.62 \\
0.0049\end{array}$ & $\begin{array}{c}47.0 \\
0.67 \\
20.0 \\
0.72 \\
0.0042\end{array}$ & $\begin{array}{c}52.4 \\
0.62 \\
24.6 \\
0.54 \\
0.0049\end{array}$ & $\begin{array}{l}51.1 \\
0.63 \\
15.0 \\
0.65 \\
0.0051\end{array}$ & $\begin{array}{l}52.9 \\
0.61 \\
26.9 \\
0.54 \\
0.0051\end{array}$ & $\begin{array}{c}51.2 \\
0.63 \\
13.7 \\
0.68 \\
0.0050\end{array}$ & $\begin{array}{c}53.5 \\
0.61 \\
24.2 \\
0.60 \\
0.0049\end{array}$ & $\begin{array}{l}54.0 \\
0.60 \\
27.1 \\
0.55 \\
0.0051\end{array}$ & $\begin{array}{l}54.3 \\
0.60 \\
21.1 \\
0.62 \\
0.0044\end{array}$ & $\begin{array}{c}48.9 \\
0.65 \\
29.1 \\
0.56 \\
0.0051\end{array}$ \\
\hline
\end{tabular}


Table 1 (continued).

\begin{tabular}{|c|c|c|c|c|c|c|c|c|c|c|c|c|}
\hline $\begin{array}{l}\text { Leg: } \\
\text { Core-section: } \\
\text { Interval }(\mathrm{cm}): \\
\text { Piece no.: } \\
\text { Depth (mbsf): } \\
\text { Lithologic unit*: } \\
\text { Unit rock name: } \\
\text { Alteration (\%): } \\
\text { Alteration type: }\end{array}$ & $\begin{array}{c}140 \\
197 \mathrm{R} 01 \\
123-126 \\
27 \\
1704.0 \\
223 \\
\text { sPOCD } \\
15 \\
\text { D }\end{array}$ & $\begin{array}{c}140 \\
198 \mathrm{R} 01 \\
50-54 \\
14 \\
1712.7 \\
223 \\
\text { sPOCD } \\
20 \\
\text { D }\end{array}$ & $\begin{array}{c}140 \\
198 \mathrm{R} 01 \\
79-82 \\
20 \\
1713.0 \\
224 \\
\mathrm{AD} \\
75 \\
\mathrm{~L}\end{array}$ & $\begin{array}{c}140 \\
199 \mathrm{R} 01 \\
54-57 \\
13 \\
1719.9 \\
226 \\
\mathrm{mPOCD} \\
15 \\
\mathrm{D}\end{array}$ & $\begin{array}{c}140 \\
199 \mathrm{R} 01 \\
89-92 \\
21 \\
1720.3 \\
226 \\
\mathrm{mPOCD} \\
15 \\
\mathrm{D}\end{array}$ & $\begin{array}{c}140 \\
200 \mathrm{R} 01 \\
35-39 \\
8 \\
1729.0 \\
227 \\
\text { mPOCD } \\
10 \\
\text { D }\end{array}$ & $\begin{array}{c}140 \\
200 \mathrm{R} 02 \\
53-57 \\
7 \mathrm{~B} \\
1730.6 \\
227 \\
\mathrm{mPOCD} \\
10 \\
\mathrm{D}\end{array}$ & $\begin{array}{c}140 \\
200 \mathrm{R} 02 \\
116-119 \\
18 \\
1731.3 \\
227 \\
\mathrm{mPOCD} \\
10 \\
\mathrm{D}\end{array}$ & $\begin{array}{c}140 \\
200 \mathrm{R} 03 \\
115-117 \\
18 \\
1732.8 \\
227 \\
\mathrm{mPOCD} \\
15 \\
\mathrm{D}\end{array}$ & $\begin{array}{c}140 \\
200 \mathrm{R} 04 \\
16-19 \\
4 \\
1733.3 \\
227 \\
\mathrm{mPOCD} \\
20 \\
\mathrm{~L}\end{array}$ & $\begin{array}{c}140 \\
202 \mathrm{R} 01 \\
9-12 \\
3 \\
1747.3 \\
229 \\
\text { sPOCD } \\
10 \\
\text { D }\end{array}$ & $\begin{array}{c}140 \\
202 \mathrm{RO} 1 \\
23-25 \\
7 \\
1747.4 \\
229 \\
\text { sPOCD } \\
25 \\
\mathrm{H}\end{array}$ \\
\hline $\begin{array}{l}\mathrm{SiO}_{2}(\mathrm{wt} \%) \\
\mathrm{TiO}_{2} \\
\mathrm{Al}_{2} \mathrm{O}_{3} \\
\mathrm{Fe}_{2} \mathrm{O}_{3} \\
\mathrm{FeO} \\
\mathrm{MnO} \\
\mathrm{MgO} \\
\mathrm{CaO} \\
\mathrm{Na}_{2} \mathrm{O} \\
\mathrm{P}_{2} \mathrm{O}_{5} \\
\mathrm{H}_{2} \mathrm{O}^{+}\end{array}$ & $\begin{array}{c}49.1 \\
0.80 \\
16.0 \\
2.69 \\
6.49 \\
0.16 \\
9.41 \\
13.0 \\
1.63 \\
0.06 \\
1.71\end{array}$ & $\begin{array}{c}49.3 \\
0.83 \\
15.8 \\
2.61 \\
6.74 \\
0.17 \\
9.51 \\
12.8 \\
1.67 \\
0.06 \\
1.41\end{array}$ & $\begin{array}{c}49.4 \\
0.91 \\
15.6 \\
2.27 \\
6.87 \\
0.17 \\
8.66 \\
13.4 \\
1.69 \\
0.06 \\
1.59\end{array}$ & $\begin{array}{c}49.4 \\
0.79 \\
16.4 \\
2.20 \\
6.30 \\
0.16 \\
9.60 \\
13.0 \\
1.71 \\
0.06 \\
1.27\end{array}$ & $\begin{array}{c}48.3 \\
0.75 \\
15.8 \\
1.67 \\
7.23 \\
0.17 \\
9.43 \\
12.7 \\
1.60 \\
0.05 \\
1.75\end{array}$ & $\begin{array}{c}50.0 \\
0.79 \\
16.6 \\
1.92 \\
6.46 \\
0.15 \\
9.63 \\
13.2 \\
1.72 \\
0.06 \\
1.18\end{array}$ & $\begin{array}{c}49.4 \\
0.76 \\
16.5 \\
2.37 \\
5.97 \\
0.15 \\
9.65 \\
13.1 \\
1.68 \\
0.06 \\
1.09\end{array}$ & $\begin{array}{c}49.2 \\
0.78 \\
16.2 \\
2.10 \\
6.57 \\
0.17 \\
9.50 \\
13.2 \\
1.65 \\
0.06 \\
1.51\end{array}$ & $\begin{array}{c}48.2 \\
0.70 \\
16.4 \\
1.72 \\
6.55 \\
0.16 \\
10.04 \\
12.8 \\
1.45 \\
0.05 \\
2.16\end{array}$ & $\begin{array}{c}49.1 \\
0.75 \\
16.2 \\
1.97 \\
6.33 \\
0.15 \\
9.75 \\
13.1 \\
1.63 \\
0.06 \\
1.51\end{array}$ & $\begin{array}{c}49.4 \\
0.84 \\
15.7 \\
2.13 \\
7.17 \\
0.18 \\
9.05 \\
12.9 \\
1.77 \\
0.07 \\
1.06\end{array}$ & $\begin{array}{c}49.7 \\
0.84 \\
15.7 \\
1.67 \\
7.50 \\
0.20 \\
8.77 \\
13.1 \\
1.68 \\
0.06 \\
1.40\end{array}$ \\
\hline Sum & 101.1 & 100.9 & 100.6 & 100.9 & 99.5 & 101.7 & 100.7 & 100.9 & 100.2 & 100.6 & 100.3 & 100.6 \\
\hline $\mathrm{Fe}_{2} \mathrm{O}_{3 \mathrm{~T}}$ & 9.9 & 10.1 & 9.9 & 9.2 & 9.7 & 9.1 & 9.0 & 9.4 & 9.0 & 9.0 & 10.1 & 10.0 \\
\hline $\begin{array}{l}\mathrm{S}(\mathrm{ppm}) \\
\mathrm{Cr} \\
\mathrm{Ni} \\
\mathrm{Cu} \\
\mathrm{Zn} \\
\mathrm{Ga} \\
\mathrm{Sr} \\
\mathrm{Y} \\
\mathrm{Zr}\end{array}$ & $\begin{array}{r}338 \\
355 \\
150 \\
112 \\
68 \\
15 \\
50 \\
25 \\
41\end{array}$ & $\begin{array}{r}596 \\
336 \\
146 \\
101 \\
62 \\
14 \\
53 \\
23 \\
23 \\
43\end{array}$ & $\begin{array}{r}58 \\
443 \\
105 \\
9 \\
50 \\
16 \\
62 \\
26 \\
44\end{array}$ & $\begin{array}{r}1005 \\
367 \\
158 \\
88 \\
63 \\
14 \\
65 \\
19 \\
43\end{array}$ & $\begin{array}{r}860 \\
382 \\
160 \\
386 \\
74 \\
13 \\
62 \\
22 \\
42\end{array}$ & $\begin{array}{r}1030 \\
374 \\
157 \\
86 \\
59 \\
14 \\
67 \\
19 \\
42\end{array}$ & $\begin{array}{r}956 \\
388 \\
158 \\
86 \\
63 \\
13 \\
67 \\
19 \\
42\end{array}$ & $\begin{array}{r}621 \\
377 \\
154 \\
99 \\
77 \\
14 \\
66 \\
23 \\
43\end{array}$ & $\begin{array}{r}770 \\
378 \\
191 \\
75 \\
92 \\
13 \\
61 \\
21 \\
38\end{array}$ & $\begin{array}{r}839 \\
381 \\
161 \\
88 \\
65 \\
13 \\
65 \\
20 \\
41\end{array}$ & $\begin{array}{r}1140 \\
339 \\
123 \\
93 \\
64 \\
14 \\
55 \\
24 \\
44 \\
44\end{array}$ & $\begin{array}{r}1000 \\
339 \\
117 \\
503 \\
58 \\
14 \\
52 \\
27 \\
44\end{array}$ \\
\hline $\begin{array}{l}\mathrm{FM} \\
\mathrm{Mg} \# \\
\mathrm{Ox} \\
\mathrm{Y} / \mathrm{Zr} \\
\mathrm{Zr} / \mathrm{TiO}_{2}\end{array}$ & $\begin{array}{l}48.6 \\
0.65 \\
27.1 \\
0.61 \\
0.0051\end{array}$ & $\begin{array}{l}48.9 \\
0.65 \\
25.8 \\
0.53 \\
0.0052\end{array}$ & $\begin{array}{l}50.7 \\
0.63 \\
22.9 \\
0.59 \\
0.0048\end{array}$ & $\begin{array}{l}46.3 \\
0.67 \\
23.9 \\
0.44 \\
0.0054\end{array}$ & $\begin{array}{l}48.1 \\
0.66 \\
17.2 \\
0.52 \\
0.0056\end{array}$ & $\begin{array}{c}46.0 \\
0.68 \\
21.1 \\
0.45 \\
0.0053\end{array}$ & $\begin{array}{l}45.6 \\
0.68 \\
26.3 \\
0.45 \\
0.0055\end{array}$ & $\begin{array}{l}47.1 \\
0.67 \\
22.3 \\
0.53 \\
0.0055\end{array}$ & $\begin{array}{l}44.6 \\
0.69 \\
19.1 \\
0.55 \\
0.0054\end{array}$ & $\begin{array}{l}45.4 \\
0.68 \\
21.8 \\
0.49 \\
0.0055\end{array}$ & $\begin{array}{l}50.1 \\
0.64 \\
21.1 \\
0.55 \\
0.0052\end{array}$ & $\begin{array}{c}50.6 \\
0.63 \\
16.7 \\
0.61 \\
0.0052\end{array}$ \\
\hline
\end{tabular}

Table 1 (continued).

\begin{tabular}{|c|c|c|c|c|c|c|c|c|c|c|c|c|}
\hline Leg: & 140 & 140 & 140 & 140 & 140 & 140 & 140 & 140 & 140 & 140 & 140 & 140 \\
\hline Core-section: & 203 R01 & 204 R01 & 204 R01 & 205 R01 & 207 R01 & 208 R01 & 208 R01 & 208 R02 & $208 \mathrm{R} 03$ & 209 R01 & 209 R01 & 209 R01 \\
\hline Interval $(\mathrm{cm})$ : & $12-14$ & $0-4$ & $15-19$ & $21-23$ & $22-26$ & $88-91$ & $110-114$ & $0-6$ & $7-10$ & $35-41 \mathrm{~A}$ & $35-41 B$ & $98-102$ \\
\hline Piece no.: & 4 & 1 & 4 & 3 & 6 & 19 & 23 & 1 & 1 & $6 \mathrm{~A}$ & $6 \mathrm{~A}$ & 14 \\
\hline Depth (mbsf): & 1749.1 & 1756.5 & 1756.7 & 1757.2 & 1768.6 & 1778.9 & 1779.1 & 1779.5 & 1781.1 & 1787.9 & 1787.9 & 1788.5 \\
\hline Lithologic unit*: & 231 & 232 & 232 & 232 & 236 & 239 & 239 & 239 & 239 & 240 & 240 & 240 \\
\hline Unit rock name: & $\mathrm{AD}$ & sPCOD & sPCOD & sPCOD & $\mathrm{AD}$ & mOPCD & $\mathrm{mOPCD}$ & mOPCD & mOPCD & mOPCD & mOPCD & $\mathrm{mOPCD}$ \\
\hline Alteration (\%): & 15 & & 45 & 40 & 40 & 35 & 18 & 40 & 75 & 15 & 50 & 78 \\
\hline Alteration type: & D & L & L & L & D & $\mathrm{H}$ & D & L & $P$ & D & $P$ & $P$ \\
\hline $\mathrm{SiO}_{2}(\mathrm{wt} \%)$ & 49.5 & 48.0 & 48.7 & 48.1 & 50.5 & 49.4 & 50.2 & 50.0 & 50.0 & 49.1 & 49.0 & 49.3 \\
\hline $\mathrm{TiO}_{2}$ & 0.91 & 0.99 & 0.95 & 0.98 & 1.06 & 0.86 & 0.89 & 0.83 & 0.56 & 0.79 & 0.61 & 0.42 \\
\hline $\mathrm{Al}_{2} \mathrm{O}_{3}$ & 15.2 & 15.8 & 15.3 & 15.9 & 14.1 & 16.0 & 15.9 & 16.0 & 16.4 & 17.9 & 17.2 & 15.9 \\
\hline $\mathrm{Fe}_{2} \mathrm{O}_{3}$ & 2.35 & 2.48 & 2.43 & 2.18 & 2.28 & 2.51 & 2.44 & 2.29 & 2.09 & 1.75 & 1.70 & 2.07 \\
\hline $\mathrm{FeO}$ & 7.33 & 6.95 & 6.36 & 6.14 & 7.85 & 7.19 & 6.62 & 6.76 & 7.12 & 6.16 & 6.93 & 8.22 \\
\hline $\mathrm{MnO}$ & 0.19 & 0.16 & 0.15 & 0.15 & 0.19 & 0.17 & 0.17 & 0.17 & 0.16 & 0.14 & 0.15 & 0.16 \\
\hline $\mathrm{MgO}$ & 8.94 & 9.23 & 8.92 & 9.26 & 8.76 & 8.66 & 8.69 & 8.82 & 8.69 & 8.54 & 9.03 & 9.23 \\
\hline $\mathrm{CaO}$ & 13.1 & 13.8 & 13.9 & 13.8 & 12.8 & 12.5 & 13.2 & 13.1 & 11.9 & 13.3 & 12.6 & 11.4 \\
\hline $\mathrm{Na}_{2} \mathrm{O}$ & 1.85 & 1.58 & 1.77 & 1.66 & 1.82 & 1.74 & 1.76 & 1.72 & 1.83 & 1.73 & 1.70 & 1.61 \\
\hline $\mathrm{P}_{2} \mathrm{O}_{5}$ & 0.07 & 0.09 & 0.09 & 0.09 & 0.08 & 0.06 & 0.07 & 0.06 & 0.03 & 0.07 & 0.05 & 0.03 \\
\hline $\mathrm{H}_{2} \mathrm{O}^{+}$ & 1.62 & 2.12 & 1.98 & 2.11 & 1.10 & 1.95 & 1.25 & 1.48 & 3.36 & 1.74 & 2.44 & 3.12 \\
\hline Sum & 101.1 & 101.2 & 100.6 & 100.4 & 100.5 & 101.0 & 101.2 & 101.2 & 102.1 & 101.2 & 101.4 & 101.5 \\
\hline $\mathrm{Fe}_{2} \mathrm{O}_{3 \mathrm{~T}}$ & 10.5 & 10.2 & 9.5 & 9.0 & 11.0 & 10.5 & 9.8 & 9.8 & 10.0 & 8.6 & 9.4 & 11.2 \\
\hline $\mathrm{S}$ (ppm) & 619 & 60 & 245 & 212 & 142 & 1730 & 128 & 784 & n.d. & 1010 & 56 & n.d. \\
\hline $\mathrm{Cr}$ & 364 & 362 & 357 & 346 & 273 & 369 & 337 & 341 & 396 & 312 & 365 & 413 \\
\hline $\mathrm{Ni}$ & 105 & 135 & 120 & 137 & 90 & 109 & 102 & 108 & 125 & 128 & 126 & 128 \\
\hline $\mathrm{Cu}$ & 158 & 8 & 8 & 13 & 55 & 171 & 98 & 82 & 12 & 120 & 33 & 9 \\
\hline $\mathrm{Zn}$ & 62 & 46 & 43 & 57 & 50 & 65 & 56 & 55 & 54 & 49 & 54 & 65 \\
\hline $\mathrm{Ga}$ & 16 & 16 & 15 & 15 & 14 & 15 & 14 & 15 & n.d. & 14 & 14 & 13 \\
\hline $\mathrm{Sr}$ & 53 & 67 & 70 & 68 & 55 & 55 & 59 & 57 & 57 & 60 & 55 & 50 \\
\hline $\mathrm{Y}$ & 27 & 29 & 27 & 29 & 28 & 24 & 23 & 22 & 14 & 23 & 18 & 12 \\
\hline $\mathrm{Zr}$ & 46 & 62 & 60 & 62 & 53 & 45 & 47 & 44 & 31 & 43 & 32 & 25 \\
\hline $\mathrm{FM}$ & 51.4 & 49.9 & 48.9 & 46.7 & 53.0 & 52.2 & 50.4 & 50.0 & 50.9 & 47.5 & 48.4 & 52.2 \\
\hline $\mathrm{Mg} \#$ & 0.63 & 0.64 & 0.65 & 0.67 & 0.61 & 0.62 & 0.64 & 0.64 & 0.63 & 0.66 & 0.66 & 0.62 \\
\hline Ox & 22.4 & 24.3 & 25.6 & 24.2 & 20.7 & 23.9 & 24.9 & 23.3 & 20.9 & 20.4 & 18.1 & 18.4 \\
\hline $\mathrm{Y} / \mathrm{Zr}$ & 0.59 & 0.47 & 0.45 & 0.47 & 0.53 & 0.53 & 0.49 & 0.50 & 0.45 & 0.53 & 0.56 & 0.48 \\
\hline $\mathrm{Zr} / \mathrm{TiO}_{2}$ & 0.0051 & 0.0063 & 0.0063 & 0.0063 & 0.0050 & 0.0052 & 0.0053 & 0.0053 & 0.0055 & 0.0054 & 0.0052 & 0.0060 \\
\hline
\end{tabular}


Table 1 (continued).

\begin{tabular}{|c|c|c|c|c|c|c|c|c|c|c|c|c|}
\hline $\begin{array}{l}\text { Leg: } \\
\text { Core-section: } \\
\text { Interval (cm): } \\
\text { Piece no.: } \\
\text { Depth (mbsf): } \\
\text { Lithologic unit*: } \\
\text { Unit rock name: } \\
\text { Alteration (\%): } \\
\text { Alteration type: }\end{array}$ & $\begin{array}{c}140 \\
209 \mathrm{ROI} \\
129-132 \\
15 \\
1788.8 \\
240 \\
\text { mOPCD } \\
20 \\
\text { D }\end{array}$ & $\begin{array}{c}140 \\
20902 \\
68-70 \\
10 \\
1789.6 \\
240 \\
\text { mOPCD } \\
15 \\
\text { D }\end{array}$ & $\begin{array}{c}140 \\
210 \mathrm{R} 01 \\
33-37 \\
4 \mathrm{C} \\
1795.2 \\
241 \\
\mathrm{SPOCD} \\
15 \\
\mathrm{D}\end{array}$ & $\begin{array}{c}140 \\
210 \text { R01 } \\
80-87 \\
12 \\
1795.7 \\
241 \\
\text { sPOCD } \\
\text { D }\end{array}$ & $\begin{array}{c}140 \\
211 \mathrm{R} 01 \\
70-74 \\
16 \\
1799.2 \\
241 \\
\text { sPOCD } \\
30 \\
\text { D }\end{array}$ & $\begin{array}{c}140 \\
213 \mathrm{R} 01 \\
64-68 \\
19 \\
1813.1 \\
243 \\
\text { sPOCD } \\
35 \\
\text { D }\end{array}$ & $\begin{array}{c}140 \\
214 \mathrm{R} 01 \\
24-28 \\
5 \mathrm{~A} \\
1818.9 \\
244 \\
\mathrm{mPOCD} \\
82 \\
\mathrm{P}\end{array}$ & $\begin{array}{c}140 \\
214 \mathrm{R} 01 \\
36-40 \\
5 \\
1819.0 \\
244 \\
\mathrm{mPOCD} \\
50 \\
\mathrm{D}\end{array}$ & $\begin{array}{c}140 \\
214 \mathrm{R} 01 \\
73-76 \\
8 \\
1819.3 \\
244 \\
\mathrm{mPOCD} \\
90 \\
\mathrm{P}\end{array}$ & $\begin{array}{c}140 \\
215 \mathrm{R} 01 \\
39-43 \\
11 \\
1823.5 \\
244 \\
\mathrm{mPOCD} \\
40 \\
\mathrm{~L}\end{array}$ & $\begin{array}{c}140 \\
215 \mathrm{R} 01 \\
59-63 \\
12 \\
1823.6 \\
244 \\
\mathrm{mPOCD} \\
15 \\
\text { D }\end{array}$ & $\begin{array}{c}140 \\
215 \mathrm{R} 01 \\
81-85 \\
20 \\
1823.8 \\
244 \\
\mathrm{mPOCD} \\
20 \\
\mathrm{D}\end{array}$ \\
\hline $\begin{array}{l}\mathrm{SiO}_{2}(\mathrm{wt} \%) \\
\mathrm{TiO}_{2} \\
\mathrm{Al}_{2} \mathrm{O}_{3} \\
\mathrm{Fe}_{2} \mathrm{O}_{3} \\
\mathrm{FeO} \\
\mathrm{MnO} \\
\mathrm{MgO} \\
\mathrm{CaO} \\
\mathrm{Na}_{2} \mathrm{O} \\
\mathrm{P}_{2} \mathrm{O}_{5} \\
\mathrm{H}_{2} \mathrm{O}^{+}\end{array}$ & $\begin{array}{c}48.9 \\
0.80 \\
17.2 \\
2.13 \\
6.09 \\
0.16 \\
8.49 \\
13.4 \\
1.69 \\
0.07 \\
1.56\end{array}$ & $\begin{array}{c}49.1 \\
0.74 \\
17.6 \\
2.45 \\
5.53 \\
0.15 \\
8.51 \\
13.5 \\
1.69 \\
0.06 \\
1.26\end{array}$ & $\begin{array}{c}50.0 \\
0.85 \\
16.0 \\
2.40 \\
6.57 \\
0.16 \\
8.85 \\
13.1 \\
1.79 \\
0.07 \\
0.97\end{array}$ & $\begin{array}{c}49.9 \\
0.87 \\
15.4 \\
\text { n.d. } \\
\text { n.d. } \\
0.16 \\
8.82 \\
13.6 \\
1.90 \\
0.06 \\
1.29\end{array}$ & $\begin{array}{c}49.2 \\
0.82 \\
16.2 \\
2.40 \\
6.48 \\
0.15 \\
9.19 \\
13.9 \\
1.71 \\
0.07 \\
1.72\end{array}$ & $\begin{array}{c}49.1 \\
0.78 \\
16.2 \\
2.21 \\
6.56 \\
0.15 \\
9.33 \\
13.1 \\
1.77 \\
0.06 \\
1.94\end{array}$ & $\begin{array}{c}49.1 \\
0.53 \\
15.9 \\
2.20 \\
6.93 \\
0.13 \\
9.67 \\
12.1 \\
1.73 \\
0.10 \\
2.62\end{array}$ & $\begin{array}{c}49.4 \\
0.71 \\
17.0 \\
1.38 \\
5.69 \\
0.12 \\
9.31 \\
13.9 \\
1.86 \\
0.06 \\
1.84\end{array}$ & $\begin{array}{c}48.8 \\
0.41 \\
13.9 \\
2.07 \\
6.78 \\
0.12 \\
8.99 \\
12.4 \\
1.72 \\
0.04 \\
3.85\end{array}$ & $\begin{array}{c}49.4 \\
0.80 \\
15.8 \\
2.05 \\
7.06 \\
0.16 \\
9.23 \\
13.0 \\
1.72 \\
0.06 \\
1.84\end{array}$ & $\begin{array}{c}49.2 \\
0.82 \\
15.9 \\
2.38 \\
6.68 \\
0.16 \\
9.13 \\
13.1 \\
1.77 \\
0.06 \\
1.49\end{array}$ & $\begin{array}{c}48.6 \\
0.90 \\
15.6 \\
3.17 \\
6.60 \\
0.19 \\
8.81 \\
13.4 \\
1.81 \\
0.07 \\
1.67\end{array}$ \\
\hline Sum & 100.5 & 100.6 & 100.8 & 101.5 & 101.8 & 101.2 & 101.0 & 101.3 & 99.1 & 101.1 & 100.7 & 100.8 \\
\hline $\mathrm{Fe}_{2} \mathrm{O}_{3 \mathrm{~T}}$ & 8.9 & 8.6 & 9.7 & 9.5 & 9.6 & 9.5 & 9.9 & 7.7 & 9.6 & 9.9 & 9.8 & 10.5 \\
\hline $\begin{array}{l}\mathrm{S} \text { (ppm) } \\
\mathrm{Cr} \\
\mathrm{Ni} \\
\mathrm{Cu} \\
\mathrm{Zn} \\
\mathrm{Ga} \\
\mathrm{Sr} \\
\mathrm{Y} \\
\mathrm{Zr}\end{array}$ & $\begin{array}{r}1110 \\
329 \\
121 \\
100 \\
53 \\
16 \\
60 \\
21 \\
43\end{array}$ & $\begin{array}{l}943 \\
343 \\
126 \\
88 \\
49 \\
15 \\
61 \\
19 \\
40\end{array}$ & $\begin{array}{r}1050 \\
348 \\
109 \\
86 \\
59 \\
14 \\
59 \\
23 \\
45\end{array}$ & $\begin{array}{l}\text { n.d. } \\
372 \\
105 \\
73 \\
49 \\
15 \\
56 \\
27 \\
45\end{array}$ & $\begin{array}{r}338 \\
337 \\
129 \\
104 \\
46 \\
13 \\
53 \\
23 \\
43\end{array}$ & $\begin{array}{r}282 \\
326 \\
129 \\
73 \\
45 \\
13 \\
53 \\
22 \\
39\end{array}$ & $\begin{array}{c}\text { n.d. } \\
473 \\
166 \\
11 \\
39 \\
\text { n.d. } \\
49 \\
15 \\
26\end{array}$ & $\begin{array}{r}37 \\
299 \\
132 \\
13 \\
39 \\
13 \\
56 \\
20 \\
36\end{array}$ & $\begin{array}{r}6370 \\
376 \\
143 \\
5 \\
42 \\
12 \\
50 \\
16 \\
23\end{array}$ & $\begin{array}{l}595 \\
370 \\
125 \\
87 \\
53 \\
14 \\
51 \\
23 \\
40\end{array}$ & $\begin{array}{l}823 \\
348 \\
130 \\
100 \\
53 \\
14 \\
54 \\
25 \\
42\end{array}$ & $\begin{array}{r}889 \\
362 \\
112 \\
96 \\
65 \\
14 \\
56 \\
28 \\
48\end{array}$ \\
\hline $\begin{array}{l}\mathrm{FM} \\
\mathrm{Mg \#} \\
\mathrm{Ox} \\
\mathrm{Y} / \mathrm{Zr} \\
\mathrm{Zr} / \mathrm{TiO}_{2}\end{array}$ & $\begin{array}{c}48.5 \\
0.65 \\
24.0 \\
0.49 \\
0.0054\end{array}$ & $\begin{array}{c}47.6 \\
0.66 \\
28.5 \\
0.48 \\
0.0054\end{array}$ & $\begin{array}{c}49.7 \\
0.64 \\
24.7 \\
0.51 \\
0.0053\end{array}$ & $\begin{array}{l}49.2 \\
0.67 \\
\\
0.60 \\
0.0052\end{array}$ & $\begin{array}{c}48.5 \\
0.65 \\
25.0 \\
0.53 \\
0.0052\end{array}$ & $\begin{array}{c}47.8 \\
0.66 \\
23.3 \\
0.56 \\
0.0050\end{array}$ & $\begin{array}{c}47.9 \\
0.66 \\
22.2 \\
0.58 \\
0.0049\end{array}$ & $\begin{array}{c}42.7 \\
0.71 \\
17.9 \\
0.56 \\
0.0051\end{array}$ & $\begin{array}{c}49.0 \\
0.65 \\
21.5 \\
0.70 \\
0.0056\end{array}$ & $\begin{array}{c}49.1 \\
0.65 \\
20.7 \\
0.58 \\
0.0050\end{array}$ & $\begin{array}{c}49.1 \\
0.65 \\
24.3 \\
0.60 \\
0.0051\end{array}$ & $\begin{array}{l}51.7 \\
0.62 \\
30.1 \\
0.58 \\
0.0053\end{array}$ \\
\hline
\end{tabular}

Table 1 (continued).

\begin{tabular}{|c|c|c|c|c|c|c|c|c|c|c|c|c|}
\hline $\begin{array}{l}\text { Leg: } \\
\text { Core-section: } \\
\text { Interval (cm): } \\
\text { Piece no.: } \\
\text { Depth (mbsf): } \\
\text { Lithologic unit*: } \\
\text { Unit rock name: } \\
\text { Alteration (\%): } \\
\text { Alteration type: }\end{array}$ & $\begin{array}{c}140 \\
216 \text { R01 } \\
54-56 \\
12 \\
1828.4 \\
245 \\
\text { mCOPD } \\
15 \\
\text { D }\end{array}$ & $\begin{array}{c}140 \\
218 \mathrm{R} 01 \\
7-9 \\
2 \\
2 \\
1847.0 \\
247 \\
\mathrm{AD} \\
55 \\
\mathrm{~L}\end{array}$ & $\begin{array}{c}140 \\
220 \mathrm{R} 01 \\
23-26 \\
6 \\
1865.7 \\
252 \\
\mathrm{mCOPD} \\
10 \\
\mathrm{D}\end{array}$ & $\begin{array}{c}140 \\
222 \mathrm{R} 01 \\
69-73 \\
12 \mathrm{~A} \\
1885.3 \\
254 \\
\mathrm{mCOPD} \\
45 \\
\mathrm{D}\end{array}$ & $\begin{array}{c}140 \\
222 \mathrm{R} 01 \\
115-120 \mathrm{~A} \\
12 \\
1885.8 \\
256 \\
\mathrm{AD} \\
45 \\
\mathrm{D}\end{array}$ & $\begin{array}{c}140 \\
222 \mathrm{R} 01 \\
115-120 \mathrm{~B} \\
22 \\
1885.8 \\
256 \\
\mathrm{AD} \\
70 \\
\mathrm{P}\end{array}$ & $\begin{array}{c}140 \\
224 \text { R01 } \\
38-42 \\
8 \\
1904.1 \\
258 \\
\text { mCPOD } \\
8 \\
\text { D }\end{array}$ & $\begin{array}{c}140 \\
224 \text { R01 } \\
71-74 \\
13 \\
1904.4 \\
258 \\
\text { mCPOD } \\
60 \\
\text { L }\end{array}$ & $\begin{array}{l}140 \\
225 \mathrm{R} 01 \\
107-109 \\
27 \\
1913.3 \\
259 \\
\text { AD } \\
50 \\
\mathrm{~L}\end{array}$ & $\begin{array}{c}140 \\
225 \mathrm{R} 02 \\
29-32 \\
5 \\
1914.0 \\
260 \\
\text { mCOPD } \\
15 \\
\text { D }\end{array}$ & $\begin{array}{c}140 \\
225 \mathrm{R} 02 \\
68-72 \mathrm{~A} \\
13 \\
1914.4 \\
260 \\
\text { mCOPD } \\
20 \\
\text { D }\end{array}$ & $\begin{array}{c}140 \\
225 \mathrm{R} 02 \\
68-72 \mathrm{~B} \\
13 \\
1914.4 \\
260 \\
\text { mCOPD } \\
70 \\
\mathrm{H}\end{array}$ \\
\hline $\begin{array}{l}\mathrm{SiO}_{2}(\mathrm{wt} \%) \\
\mathrm{TiO}_{2} \\
\mathrm{Al}_{2} \mathrm{O}_{3} \\
\mathrm{Fe}_{2} \mathrm{O}_{3} \\
\mathrm{FeO} \\
\mathrm{MnO} \\
\mathrm{MgO} \\
\mathrm{CaO} \\
\mathrm{Na}_{2} \mathrm{O} \\
\mathrm{P}_{2} \mathrm{O}_{5} \\
\mathrm{H}_{2} \mathrm{O}^{+}\end{array}$ & $\begin{array}{c}49.2 \\
0.84 \\
16.1 \\
2.03 \\
6.72 \\
0.17 \\
8.64 \\
13.3 \\
2.00 \\
0.07 \\
2.05\end{array}$ & $\begin{array}{c}49.7 \\
1.06 \\
14.7 \\
2.37 \\
7.95 \\
0.19 \\
8.47 \\
12.5 \\
2.19 \\
0.08 \\
2.13\end{array}$ & $\begin{array}{c}0.4 \\
0.96 \\
15.0 \\
2.74 \\
7.16 \\
0.18 \\
8.44 \\
12.9 \\
1.78 \\
0.07 \\
1.32\end{array}$ & $\begin{array}{c}46.8 \\
0.95 \\
16.6 \\
2.01 \\
6.92 \\
0.16 \\
10.01 \\
12.7 \\
1.61 \\
0.09 \\
3.22\end{array}$ & $\begin{array}{c}8.0 \\
1.01 \\
16.1 \\
2.00 \\
6.21 \\
0.14 \\
9.37 \\
13.9 \\
1.80 \\
0.09 \\
2.43\end{array}$ & $\begin{array}{c}8.4 \\
1.04 \\
15.8 \\
2.29 \\
6.31 \\
0.14 \\
9.43 \\
13.1 \\
2.12 \\
0.09 \\
2.42\end{array}$ & $\begin{array}{c}50.0 \\
0.90 \\
15.9 \\
2.90 \\
6.39 \\
0.16 \\
8.22 \\
13.2 \\
1.75 \\
0.07 \\
1.49\end{array}$ & $\begin{array}{c}50.9 \\
1.04 \\
14.8 \\
2.20 \\
7.02 \\
0.16 \\
8.67 \\
13.3 \\
1.87 \\
0.08 \\
1.11\end{array}$ & $\begin{array}{c}49.5 \\
0.97 \\
15.5 \\
2.44 \\
6.89 \\
0.17 \\
8.97 \\
1.1 \\
1.87 \\
0.07 \\
1.47\end{array}$ & $\begin{array}{c}49.6 \\
0.82 \\
16.0 \\
2.22 \\
6.91 \\
0.17 \\
9.14 \\
13.0 \\
1.78 \\
0.07 \\
1.38\end{array}$ & $\begin{array}{c}48.9 \\
0.83 \\
16.2 \\
1.75 \\
6.88 \\
0.15 \\
9.15 \\
1.3 \\
1.74 \\
0.07 \\
1.71\end{array}$ & $\begin{array}{c}49.5 \\
0.77 \\
15.3 \\
1.95 \\
7.87 \\
0.16 \\
9.39 \\
12.7 \\
1.58 \\
0.06 \\
1.94\end{array}$ \\
\hline Sum & 101.1 & 101.3 & 101.0 & 101.1 & 101.1 & 101.1 & 101.0 & 101.2 & 101.0 & 101.1 & 100.7 & 101.2 \\
\hline $\mathrm{Fe}_{2} \mathrm{O}_{3 \mathrm{~T}}$ & 9.5 & 11.2 & 10.7 & 9.7 & 8.9 & 9.3 & 10.0 & 10.0 & 10.1 & 9.9 & 9.4 & 10.7 \\
\hline $\begin{array}{l}\mathrm{S} \text { (ppm) } \\
\mathrm{Cr} \\
\mathrm{Ni} \\
\mathrm{Cu} \\
\mathrm{Zn} \\
\mathrm{Ga} \\
\mathrm{Sr} \\
\mathrm{Y} \\
\mathrm{Zr}\end{array}$ & $\begin{array}{r}1120 \\
334 \\
104 \\
90 \\
69 \\
15 \\
56 \\
26 \\
44\end{array}$ & $\begin{array}{r}91 \\
267 \\
86 \\
35 \\
44 \\
15 \\
58 \\
30 \\
54\end{array}$ & $\begin{array}{r}947 \\
284 \\
93 \\
84 \\
72 \\
15 \\
55 \\
26 \\
50\end{array}$ & $\begin{array}{r}493 \\
307 \\
172 \\
20 \\
45 \\
14 \\
62 \\
25 \\
58\end{array}$ & $\begin{array}{r}57 \\
383 \\
143 \\
43 \\
39 \\
14 \\
66 \\
29 \\
64\end{array}$ & $\begin{array}{r}24 \\
334 \\
142 \\
20 \\
40 \\
15 \\
81 \\
30 \\
64\end{array}$ & $\begin{array}{r}1030 \\
303 \\
97 \\
87 \\
62 \\
15 \\
55 \\
25 \\
47\end{array}$ & $\begin{array}{r}24 \\
253 \\
94 \\
20 \\
32 \\
15 \\
54 \\
29 \\
55\end{array}$ & $\begin{array}{r}245 \\
402 \\
111 \\
77 \\
35 \\
14 \\
77 \\
27 \\
58\end{array}$ & $\begin{array}{r}1000 \\
355 \\
121 \\
89 \\
63 \\
14 \\
57 \\
23 \\
42\end{array}$ & $\begin{array}{r}269 \\
370 \\
135 \\
81 \\
44 \\
14 \\
53 \\
25 \\
42\end{array}$ & $\begin{array}{r}33 \\
396 \\
136 \\
16 \\
42 \\
13 \\
52 \\
24 \\
40\end{array}$ \\
\hline $\begin{array}{l}\mathrm{FM} \\
\mathrm{Mg} \# \\
\mathrm{Ox} \\
\mathrm{Y} / \mathrm{Zr} \\
\mathrm{Zr} / \mathrm{TiO}_{2}\end{array}$ & $\begin{array}{c}49.7 \\
0.64 \\
21.4 \\
0.59 \\
0.0052\end{array}$ & $\begin{array}{c}54.3 \\
0.60 \\
21.1 \\
0.56 \\
0.0051\end{array}$ & $\begin{array}{c}53.3 \\
0.61 \\
25.6 \\
0.52 \\
0.0052\end{array}$ & $\begin{array}{l}46.6 \\
0.67 \\
20.7 \\
0.43 \\
0.0061\end{array}$ & $\begin{array}{c}46.1 \\
0.68 \\
22.5 \\
0.45 \\
0.0063\end{array}$ & $\begin{array}{c}47.0 \\
0.67 \\
24.6 \\
0.47 \\
0.0062\end{array}$ & $\begin{array}{c}52.3 \\
0.62 \\
29.0 \\
0.53 \\
0.0052\end{array}$ & $\begin{array}{c}50.9 \\
0.63 \\
22.0 \\
0.53 \\
0.0053\end{array}$ & $\begin{array}{c}50.3 \\
0.64 \\
24.2 \\
0.47 \\
0.0060\end{array}$ & $\begin{array}{c}49.4 \\
0.65 \\
22.4 \\
0.55 \\
0.0051\end{array}$ & $\begin{array}{c}48.0 \\
0.66 \\
18.7 \\
0.60 \\
0.0051\end{array}$ & $\begin{array}{c}50.6 \\
0.63 \\
18.3 \\
0.60 \\
0.0052\end{array}$ \\
\hline
\end{tabular}


Table 1 (continued).

\begin{tabular}{|c|c|c|c|c|c|c|c|c|c|c|c|c|c|}
\hline $\begin{array}{l}\text { Leg: } \\
\text { Core-section: } \\
\text { Interval }(\mathrm{cm}) \text { : } \\
\text { Piece no.: } \\
\text { Depth (mbsf): } \\
\text { Lithologic unit*: } \\
\text { Unit rock name: } \\
\text { Alteration (\%): } \\
\text { Alteration type: }\end{array}$ & $\begin{array}{c}140 \\
226 \mathrm{R} 03 \\
30-34 \\
3 \\
1923.2 \\
260 \\
\mathrm{mCOPD} \\
20 \\
\mathrm{D}\end{array}$ & $\begin{array}{c}140 \\
227 \mathrm{R} 01 \\
40-46 \\
7 \\
1924.9 \\
260 \\
\mathrm{mCOPD} \\
\mathrm{D}\end{array}$ & $\begin{array}{c}140 \\
227 \mathrm{R01} \\
67-70 \\
8 \mathrm{~B} \\
1925.2 \\
260 \\
\mathrm{mCOPD} \\
60 \\
\mathrm{P}\end{array}$ & $\begin{array}{c}140 \\
229 \mathrm{R} 01 \\
31-33 \\
10 \\
1943.8 \\
265 \\
\text { sPOCD } \\
50 \\
\mathrm{~L}\end{array}$ & $\begin{array}{c}140 \\
230 \mathrm{R} 01 \\
11-14 \\
3 \\
1953.1 \\
265 \\
\text { sPOCD } \\
40 \\
\text { L }\end{array}$ & $\begin{array}{c}140 \\
231 \mathrm{R} 01 \\
0-3 \\
1 \\
1953.5 \\
265 \\
\text { sPOCD } \\
55 \\
\text { L }\end{array}$ & $\begin{array}{c}140 \\
233 \mathrm{R} 01 \\
16-18 \\
5 \\
1960.1 \\
266 \\
\mathrm{AD} \\
60 \\
\mathrm{~L}\end{array}$ & $\begin{array}{c}140 \\
235 \mathrm{R} 01 \\
21-24 \mathrm{~A} \\
7 \\
1976.3 \\
269 \\
\mathrm{mPOCD} \\
20 \\
\mathrm{D}\end{array}$ & $\begin{array}{c}140 \\
235 \mathrm{R} 01 \\
21-24 \mathrm{~B} \\
7 \\
1976.3 \\
269 \\
\mathrm{mPOCD} \\
45 \\
\mathrm{H}\end{array}$ & $\begin{array}{c}140 \\
236 \mathrm{R} 01 \\
26-28 \\
5 \\
1981.0 \\
269 \\
\mathrm{mPOCD} \\
60 \\
\mathrm{P}\end{array}$ & $\begin{array}{c}140 \\
237 \mathrm{R} 01 \\
17-19 \\
5 \\
1983.9 \\
269 \\
\mathrm{mPOCD} \\
20 \\
\mathrm{D}\end{array}$ & $\begin{array}{c}140 \\
238 \mathrm{R} 01 \\
4-7 \\
2 \\
1992.0 \\
269 \\
\mathrm{mPOCD} \\
25 \\
\mathrm{D}\end{array}$ & $\begin{array}{c}140 \\
238 \mathrm{R} 01 \\
8-9 \\
3 \\
1992.0 \\
269 \\
\text { mPOCD } \\
25 \\
\text { D }\end{array}$ \\
\hline $\begin{array}{l}\mathrm{SiO}_{2}(\mathrm{wt} \%) \\
\mathrm{TiO}_{2} \\
\mathrm{Al}_{2} \mathrm{O}_{3} \\
\mathrm{Fe}_{2} \mathrm{O}_{3} \\
\mathrm{FeO} \\
\mathrm{MnO} \\
\mathrm{MgO} \\
\mathrm{CaO} \\
\mathrm{Na}_{2} \mathrm{O} \\
\mathrm{P}_{2} \mathrm{O}_{5} \\
\mathrm{H}_{2} \mathrm{O}^{+}\end{array}$ & $\begin{array}{c}46.5 \\
0.86 \\
16.5 \\
2.54 \\
6.71 \\
0.16 \\
8.95 \\
12.8 \\
1.73 \\
0.07 \\
1.91\end{array}$ & $\begin{array}{c}48.5 \\
0.67 \\
16.6 \\
\text { n.d. } \\
\text { n.d. } \\
0.15 \\
8.97 \\
12.9 \\
1.69 \\
0.06 \\
1.55\end{array}$ & $\begin{array}{c}49.0 \\
0.54 \\
16.4 \\
1.98 \\
6.95 \\
0.16 \\
9.69 \\
12.7 \\
1.55 \\
0.05 \\
2.09\end{array}$ & $\begin{array}{c}49.5 \\
0.90 \\
15.0 \\
1.80 \\
6.75 \\
0.16 \\
8.60 \\
13.3 \\
1.72 \\
0.06 \\
1.20\end{array}$ & $\begin{array}{c}50.5 \\
1.06 \\
14.6 \\
2.59 \\
7.66 \\
0.17 \\
8.28 \\
12.5 \\
2.08 \\
0.08 \\
1.07\end{array}$ & $\begin{array}{c}51.0 \\
0.90 \\
14.7 \\
2.19 \\
7.84 \\
0.15 \\
8.34 \\
12.5 \\
1.92 \\
0.07 \\
1.38\end{array}$ & $\begin{array}{c}50.0 \\
0.94 \\
14.6 \\
2.15 \\
7.15 \\
0.16 \\
8.50 \\
12.7 \\
1.97 \\
0.07 \\
1.25\end{array}$ & $\begin{array}{c}49.4 \\
0.84 \\
16.4 \\
2.23 \\
6.27 \\
0.15 \\
8.71 \\
13.3 \\
1.84 \\
0.07 \\
1.33\end{array}$ & $\begin{array}{c}49.7 \\
0.81 \\
16.0 \\
2.27 \\
6.87 \\
0.15 \\
8.68 \\
13.3 \\
1.84 \\
0.06 \\
1.50\end{array}$ & $\begin{array}{c}49.2 \\
0.64 \\
16.7 \\
1.91 \\
6.29 \\
0.13 \\
9.30 \\
12.9 \\
1.73 \\
0.05 \\
1.90\end{array}$ & $\begin{array}{c}48.5 \\
0.84 \\
16.1 \\
2.68 \\
6.23 \\
0.16 \\
8.83 \\
13.4 \\
1.83 \\
0.06 \\
1.23\end{array}$ & $\begin{array}{c}50.1 \\
0.90 \\
15.3 \\
2.90 \\
6.39 \\
0.17 \\
9.14 \\
13.2 \\
1.82 \\
0.07 \\
1.01\end{array}$ & $\begin{array}{c}49.7 \\
0.69 \\
15.8 \\
2.10 \\
6.57 \\
0.15 \\
9.17 \\
13.2 \\
1.81 \\
0.05 \\
1.60\end{array}$ \\
\hline Sum & 98.7 & 100.1 & 101.1 & 99.0 & 100.6 & 101.0 & 99.5 & 100.5 & 101.2 & 100.8 & 99.9 & 101.0 & 100.8 \\
\hline $\mathrm{Fe}_{2} \mathrm{O}_{3 \mathrm{~T}}$ & 10.0 & 9.0 & 9.7 & 9.3 & 11.1 & 10.9 & 10.1 & 9.2 & 9.9 & 8.9 & 9.6 & 10.0 & 9.4 \\
\hline $\begin{array}{l}\mathrm{S} \text { (ppm) } \\
\mathrm{Cr} \\
\mathrm{Ni} \\
\mathrm{Cu} \\
\mathrm{Zn} \\
\mathrm{Ga} \\
\mathrm{Sr} \\
\mathrm{Y} \\
\mathrm{Zr}\end{array}$ & $\begin{array}{r}479 \\
309 \\
145 \\
137 \\
46 \\
14 \\
55 \\
23 \\
45\end{array}$ & $\begin{array}{l}\text { n.d. } \\
361 \\
139 \\
38 \\
44 \\
14 \\
55 \\
21 \\
34\end{array}$ & $\begin{array}{r}952 \\
384 \\
151 \\
9 \\
48 \\
14 \\
54 \\
17 \\
28\end{array}$ & $\begin{array}{r}60 \\
424 \\
102 \\
8 \\
32 \\
14 \\
55 \\
26 \\
48\end{array}$ & $\begin{array}{r}179 \\
166 \\
82 \\
58 \\
39 \\
15 \\
52 \\
29 \\
52\end{array}$ & $\begin{array}{r}20 \\
213 \\
84 \\
6 \\
36 \\
15 \\
48 \\
28 \\
44\end{array}$ & $\begin{array}{r}125 \\
294 \\
91 \\
47 \\
39 \\
14 \\
54 \\
28 \\
49\end{array}$ & $\begin{array}{r}741 \\
341 \\
114 \\
111 \\
45 \\
14 \\
57 \\
24 \\
43\end{array}$ & $\begin{array}{r}99 \\
372 \\
110 \\
29 \\
44 \\
15 \\
61 \\
24 \\
46\end{array}$ & $\begin{array}{r}6 \\
441 \\
147 \\
6 \\
41 \\
13 \\
58 \\
18 \\
34\end{array}$ & $\begin{array}{r}847 \\
335 \\
110 \\
128 \\
43 \\
14 \\
60 \\
23 \\
44\end{array}$ & $\begin{array}{r}695 \\
352 \\
109 \\
105 \\
49 \\
14 \\
60 \\
24 \\
48\end{array}$ & $\begin{array}{r}111 \\
384 \\
116 \\
22 \\
40 \\
14 \\
57 \\
21 \\
36\end{array}$ \\
\hline $\begin{array}{l}\mathrm{FM} \\
\mathrm{Mg} \# \\
\mathrm{Ox} \\
\mathrm{Y} / \mathrm{Zr} \\
\mathrm{Zr} / \mathrm{TiO}_{2}\end{array}$ & $\begin{array}{c}50.1 \\
0.64 \\
25.4 \\
0.51 \\
0.0052\end{array}$ & $\begin{array}{l}47.4 \\
0.69 \\
\\
0.62 \\
0.0051\end{array}$ & $\begin{array}{l}47.4 \\
0.66 \\
20.4 \\
0.61 \\
0.0052\end{array}$ & $\begin{array}{l}49.3 \\
0.65 \\
19.3 \\
0.54 \\
0.0053\end{array}$ & $\begin{array}{l}54.7 \\
0.60 \\
23.3 \\
0.56 \\
0.0049\end{array}$ & $\begin{array}{l}54.0 \\
0.60 \\
20.1 \\
0.64 \\
0.0049\end{array}$ & $\begin{array}{l}51.7 \\
0.63 \\
21.3 \\
0.57 \\
0.0052\end{array}$ & $\begin{array}{l}48.7 \\
0.65 \\
24.3 \\
0.56 \\
0.0051\end{array}$ & $\begin{array}{c}50.6 \\
0.63 \\
22.9 \\
0.52 \\
0.0057\end{array}$ & $\begin{array}{l}46.3 \\
0.67 \\
21.5 \\
0.53 \\
0.0053\end{array}$ & $\begin{array}{c}49.5 \\
0.65 \\
27.9 \\
0.52 \\
0.0052\end{array}$ & $\begin{array}{c}49.6 \\
0.64 \\
29.0 \\
0.50 \\
0.0053\end{array}$ & $\begin{array}{c}48.0 \\
0.66 \\
22.3 \\
0.58 \\
0.0052\end{array}$ \\
\hline
\end{tabular}


Table 2. Rare earth element (REE) abundances of selected Leg 137/140 diabase samples.

\begin{tabular}{|c|c|c|c|c|c|c|c|c|c|c|c|c|c|c|c|}
\hline Leg: & 137 & 137 & 140 & 140 & 140 & 140 & 140 & 140 & 140 & 140 & 140 & 140 & 140 & 140 & 140 \\
\hline Core-section: & 177 R01 & $186 \mathrm{R} 02$ & 187 R01 & 187 R01 & $189 \mathrm{R} 01$ & $189 \mathrm{R} 01$ & $189 \mathrm{R} 01$ & $189 \mathrm{R} 02$ & 193 R01 & 193 R01 & 193 R01 & $194 \mathrm{R} 01$ & 196 R01 & 197 R01 & $198 \mathrm{R} 01$ \\
\hline Interval $(\mathrm{cm})$ : & $48-51$ & $30-36$ & $59-63 \mathrm{~A}$ & $59-63 \mathrm{~B}$ & $85-88$ & $90-94 \mathrm{~A}$ & $90-94 B$ & $15-17$ & $28-31$ & $44-46$ & $58-60$ & $42-46$ & $21-26$ & $29-31$ & $50-54$ \\
\hline Piece no.: & 13 & 8 & 14 & 14 & 19 & 20 & 20 & 3 & 9 & $13 \mathrm{~A}$ & 14 & 8 & 4 & 7 & 14 \\
\hline Alteration type: & D & L & D & P & D & D & H & $\mathbf{P}$ & P & $\mathrm{H}$ & $\mathbf{P}$ & P & D & $\mathrm{H}$ & D \\
\hline La & 1.0 & 1.5 & 0.9 & 0.8 & 1.0 & 0.9 & 0.7 & 0.60 & 0.7 & 1.0 & 0.5 & 0.5 & 1.4 & 0.8 & 0.9 \\
\hline $\mathrm{Ce}$ & 5.0 & 6.8 & 4.4 & 4.1 & 5.0 & 4.7 & 3.3 & 3.0 & 2.2 & 4.9 & 2.6 & 2.4 & 5.4 & 3.8 & 4.3 \\
\hline $\mathrm{Nd}$ & 4.7 & 5.5 & 4.0 & 3.5 & 4.6 & 4.6 & 3.3 & 2.8 & 2.0 & 4.4 & 2.2 & 2.4 & 4.5 & 3.6 & 3.9 \\
\hline $\mathrm{Sm}$ & 2.1 & 2.1 & 1.8 & 1.6 & 2.0 & 2.1 & 1.6 & 1.3 & 0.7 & 2.1 & 1.5 & 1.2 & 1.8 & 1.3 & 1.5 \\
\hline Eu & 0.83 & 0.82 & 0.79 & 0.84 & 0.77 & 0.80 & 0.65 & 0.57 & 0.42 & 0.73 & 0.74 & 0.55 & 0.78 & 0.72 & 0.71 \\
\hline Gd & 3.4 & 3.4 & 3.2 & 2.7 & 3.4 & 3.3 & 2.3 & 2.2 & 1.6 & 3.0 & 1.8 & 1.8 & 3.0 & 2.7 & 3.0 \\
\hline Dy & 4.7 & 4.6 & 4.4 & 3.8 & 4.5 & 4.5 & 3.4 & 3.0 & 2.2 & 4.4 & 2.5 & 2.5 & 4.4 & 3.7 & 3.9 \\
\hline Ho & 0.99 & 0.94 & 0.93 & 0.80 & 0.95 & 0.95 & 0.69 & 0.65 & 0.43 & 0.90 & 0.47 & 0.51 & 0.94 & 0.75 & 0.79 \\
\hline $\mathrm{Er}$ & 3.1 & 2.9 & 2.8 & 2.5 & 2.9 & 3.0 & 2.2 & 1.9 & 1.4 & 2.8 & 1.5 & 1.5 & 2.8 & 2.3 & 2.6 \\
\hline $\mathrm{Yb}$ & 2.9 & 2.8 & 2.7 & 2.4 & 2.8 & 2.9 & 2.2 & 2.0 & 1.3 & 2.6 & 1.6 & 1.6 & 2.7 & 2.2 & 2.4 \\
\hline $\mathrm{Lu}$ & 0.46 & 0.44 & 0.42 & 0.38 & 0.44 & 0.46 & 0.34 & 0.30 & 0.21 & 0.38 & 0.23 & 0.24 & 0.42 & 0.34 & 0.38 \\
\hline Sum REE & 29.0 & 31.8 & 26.3 & 23.4 & 28.3 & 28.2 & 20.7 & 18.3 & 13.1 & 27.2 & 15.6 & 15.2 & 28.1 & 22.2 & 24.4 \\
\hline $\mathrm{La} / \mathrm{Sm}$ & 0.48 & 0.71 & 0.50 & 0.50 & 0.51 & 0.44 & 0.45 & 0.46 & 0.97 & 0.48 & 0.33 & 0.38 & 0.78 & 0.61 & 0.61 \\
\hline
\end{tabular}

Table 2 (continued).

\begin{tabular}{|c|c|c|c|c|c|c|c|c|c|c|c|c|c|c|c|}
\hline Leg: & 140 & 140 & 140 & 140 & 140 & 140 & 140 & 140 & 140 & 140 & 140 & 140 & 140 & 140 & 140 \\
\hline Core-section: & 199 R01 & $200 \mathrm{R} 02$ & 202 R01 & 204 R01 & 207 R01 & $208 \mathrm{R} 03$ & 209 R01 & 209 R01 & 209 R01 & $209 \mathrm{R} 02$ & 211 R01 & $213 \mathrm{R} 01$ & 214 R01 & $214 \mathrm{R} 01$ & 214 R01 \\
\hline Interval $(\mathrm{cm})$ : & $54-57$ & $53-57$ & $23-25$ & $15-19$ & $22-26$ & $7-10$ & $35-41 \mathrm{~A}$ & $35-41 B$ & $98-102$ & $68-70$ & $70-74$ & $64-68$ & $24-28$ & $36-40$ & $73-76$ \\
\hline Piece no.: & 13 & $7 \mathrm{~B}$ & 7 & 4 & 6 & 1 & $6 \mathrm{~A}$ & $6 \mathrm{~A}$ & 14 & 10 & 16 & 19 & $5 \mathrm{~A}$ & 5 & 8 \\
\hline Alteration type: & D & D & $\mathrm{H}$ & L & D & P & D & $\mathrm{P}$ & $\mathrm{P}$ & D & D & D & $\mathrm{P}$ & D & P \\
\hline $\mathrm{La}$ & 1.0 & 0.9 & 0.9 & 1.2 & 1.2 & 0.7 & 0.9 & 0.7 & 0.4 & 1.1 & 0.9 & 0.9 & 0.7 & 0.8 & 0.5 \\
\hline $\mathrm{Ce}$ & 4.4 & 4.2 & 4.4 & 6.3 & 5.2 & 3.5 & 4.4 & 3.0 & 2.0 & 4.4 & 4.1 & 4.1 & 3.3 & 3.4 & 2.3 \\
\hline $\mathrm{Nd}$ & 3.7 & 3.6 & 3.8 & 5.1 & 4.7 & 2.9 & 4.0 & 2.7 & 2.1 & 3.6 & 3.9 & 3.4 & 2.6 & 3.0 & 2.2 \\
\hline $\mathrm{Sm}$ & 1.5 & 1.4 & 1.6 & 1.9 & 2.0 & 1.4 & 1.7 & 1.2 & 1.1 & 1.6 & 1.8 & 1.4 & 1.3 & 1.4 & 1.0 \\
\hline $\mathrm{Eu}$ & 0.69 & 0.67 & 0.73 & 0.92 & 0.88 & 0.58 & 0.64 & 0.57 & 0.69 & 0.62 & 0.73 & 0.69 & 0.60 & 0.67 & 0.66 \\
\hline Gd & 2.4 & 2.5 & 2.8 & 3.3 & 3.2 & 2.0 & 2.5 & 2.1 & 1.6 & 2.7 & 3.1 & 2.6 & 2.0 & 2.5 & 1.6 \\
\hline Dy & 3.5 & 3.4 & 4.0 & 4.3 & 4.6 & 2.6 & 3.5 & 2.6 & 2.1 & 3.3 & 4.0 & 3.7 & 2.8 & 3.2 & 2.2 \\
\hline Ho & 0.73 & 0.71 & 0.86 & 0.88 & 0.95 & 0.55 & 0.74 & 0.53 & 0.43 & 0.68 & 0.84 & 0.77 & 0.57 & 0.67 & 0.40 \\
\hline $\mathrm{Er}$ & 2.1 & 2.1 & 2.6 & 2.7 & 2.9 & 1.7 & 2.3 & 1.6 & 1.3 & 2.1 & 2.6 & 2.3 & 1.8 & 2.1 & 1.4 \\
\hline $\mathrm{Yb}$ & 2.1 & 1.9 & 2.5 & 2.6 & 2.8 & 1.6 & 2.2 & 1.6 & 1.3 & 2.0 & 2.6 & 2.3 & 1.8 & 2.0 & 1.4 \\
\hline $\mathrm{Lu}$ & 0.30 & 0.31 & 0.40 & 0.39 & 0.44 & 0.26 & 0.34 & 0.25 & 0.19 & 0.32 & 0.40 & 0.35 & 0.27 & 0.31 & 0.20 \\
\hline Sum REE & 22.4 & 21.7 & 24.6 & 29.6 & 28.9 & 17.8 & 23.2 & 16.8 & 13.2 & 22.4 & 25.0 & 22.5 & 17.7 & 20.1 & 13.8 \\
\hline $\mathrm{La} / \mathrm{Sm}$ & 0.67 & 0.65 & 0.56 & 0.63 & 0.60 & 0.50 & 0.50 & 0.55 & 0.36 & 0.69 & 0.50 & 0.64 & 0.54 & 0.57 & 0.48 \\
\hline
\end{tabular}

Table 2 (continued).

\begin{tabular}{|c|c|c|c|c|c|c|c|c|c|c|c|c|c|c|}
\hline Leg & 140 & 140 & 140 & 140 & 140 & 140 & 140 & 140 & 140 & 140 & 140 & 140 & 140 & 137 \\
\hline Core-section: & 216 R01 & $220 \mathrm{R} 01$ & 222 R01 & $222 \mathrm{R} 01$ & 222 R01 & $224 \mathrm{R} 01$ & $225 \mathrm{R} 02$ & $225 \mathrm{R} 02$ & $225 \mathrm{R} 02$ & $230 \mathrm{R} 01$ & $235 \mathrm{R} 01$ & $235 \mathrm{R} 01$ & $238 \mathrm{R} 01$ & $182 \mathrm{M} 03$ \\
\hline Interval (cm): & $54-56$ & $23-26$ & $69-73$ & $115-120 \mathrm{~A}$ & $115-120 \mathrm{~B}$ & $38-42$ & $29-32$ & $68-72 \mathrm{~A}$ & $68-72 B$ & $11-14$ & $21-24 \mathrm{~A}$ & $21-24 B$ & $4-7$ & $7-20$ \\
\hline Piece no.: & 12 & 6 & $12 \mathrm{~A}$ & 12 & 22 & 8 & 5 & 13 & 13 & 3 & 7 & 7 & 2 & BAS 140 \\
\hline Alteration type: & D & D & D & D & $\mathrm{P}$ & D & D & D & $\mathrm{H}$ & $\mathrm{L}$ & D & $\mathrm{H}$ & & \\
\hline $\begin{array}{l}\mathrm{La} \\
\mathrm{Ce} \\
\mathrm{Nd} \\
\mathrm{Sm} \\
\mathrm{Eu} \\
\mathrm{Gd} \\
\mathrm{Dy} \\
\mathrm{Ho} \\
\mathrm{Er} \\
\mathrm{Yb} \\
\mathrm{Lu} \\
\mathrm{Sum} \mathrm{REE} \\
\mathrm{La} / \mathrm{Sm}\end{array}$ & $\begin{array}{l}1.0 \\
4.5 \\
4.0 \\
1.4 \\
0.72 \\
2.9 \\
4.0 \\
0.83 \\
2.5 \\
2.4 \\
0.37 \\
24.6 \\
0.68\end{array}$ & $\begin{array}{l}1.1 \\
5.4 \\
4.4 \\
1.8 \\
0.86 \\
3.1 \\
4.5 \\
0.95 \\
2.8 \\
2.7 \\
0.43 \\
28.0 \\
0.61\end{array}$ & $\begin{array}{l}1.4 \\
6.2 \\
4.8 \\
1.9 \\
0.74 \\
3.1 \\
4.2 \\
0.89 \\
2.7 \\
2.6 \\
0.41 \\
28.9 \\
0.74\end{array}$ & $\begin{array}{l}1.5 \\
6.3 \\
5.4 \\
2.2 \\
0.82 \\
3.3 \\
4.6 \\
0.99 \\
3.0 \\
2.8 \\
0.45 \\
31.4 \\
0.68\end{array}$ & $\begin{array}{l}1.3 \\
6.4 \\
5.4 \\
2.1 \\
0.83 \\
3.4 \\
4.6 \\
0.97 \\
2.9 \\
2.8 \\
0.45 \\
31.2 \\
0.62\end{array}$ & $\begin{array}{l}1.2 \\
4.7 \\
4.2 \\
1.7 \\
0.78 \\
2.9 \\
4.0 \\
0.84 \\
2.5 \\
2.4 \\
0.39 \\
25.6 \\
0.71\end{array}$ & $\begin{array}{l}1.4 \\
5.3 \\
4.2 \\
1.5 \\
0.73 \\
2.8 \\
3.9 \\
0.84 \\
2.5 \\
2.4 \\
0.38 \\
26.0 \\
0.93\end{array}$ & $\begin{array}{c}0.9 \\
3.9 \\
3.8 \\
1.6 \\
0.69 \\
2.7 \\
3.8 \\
0.79 \\
2.4 \\
2.4 \\
0.38 \\
23.4 \\
0.59\end{array}$ & $\begin{array}{l}0.8 \\
4.1 \\
3.7 \\
1.5 \\
0.84 \\
2.9 \\
3.6 \\
0.76 \\
2.3 \\
2.4 \\
0.38 \\
23.3 \\
0.53\end{array}$ & $\begin{array}{l}1.1 \\
5.3 \\
4.6 \\
1.9 \\
0.80 \\
3.4 \\
4.6 \\
0.96 \\
3.0 \\
2.8 \\
0.44 \\
28.9 \\
0.58\end{array}$ & $\begin{array}{l}1.0 \\
4.6 \\
4.0 \\
1.9 \\
0.74 \\
2.9 \\
4.0 \\
0.82 \\
2.5 \\
2.4 \\
0.37 \\
25.2 \\
0.53\end{array}$ & $\begin{array}{l}0.9 \\
4.2 \\
3.6 \\
1.7 \\
0.83 \\
2.7 \\
3.7 \\
0.78 \\
2.3 \\
2.2 \\
0.34 \\
23.3 \\
0.53\end{array}$ & $\begin{array}{l}1.1 \\
4.5 \\
4.2 \\
1.7 \\
0.78 \\
2.9 \\
4.0 \\
0.84 \\
2.5 \\
2.4 \\
0.39 \\
25.3 \\
0.65\end{array}$ & $\begin{array}{l}1.0 \\
4.8 \\
4.5 \\
2.0 \\
0.61 \\
3.1 \\
3.5 \\
0.87 \\
2.6 \\
2.5 \\
0.40 \\
25.7 \\
0.51\end{array}$ \\
\hline
\end{tabular}

Notes: Alteration type: $\mathrm{D}=$ macroscopically dark, less altered diabase; $\mathrm{L}=$ macroscopically light, high background alteration; $\mathrm{H}=$ diabase containing high percentage of halos around veins; $\mathrm{P}=$ samples with green patches or vugs and a high background alteration. 
Table 3. Major and trace element data for an international reference rock BHVO-1, an interlaboratory standard Bas 140, and a comparision between shipboard and laboratory data.

\begin{tabular}{|c|c|c|c|c|c|c|c|c|}
\hline & \multicolumn{3}{|c|}{ BHVO-1 } & \multicolumn{3}{|c|}{ Bas 140} & \multicolumn{2}{|c|}{$209 \mathrm{R}-1,98-102 \mathrm{~cm}$} \\
\hline & $\begin{array}{l}\text { This } \\
\text { study }\end{array}$ & $\begin{array}{c}2 s \\
\text { std. dev. }\end{array}$ & $\begin{array}{c}\text { Govindaraju } \\
\text { (1989) }\end{array}$ & $\begin{array}{l}\text { This } \\
\text { study }\end{array}$ & $\begin{array}{c}2 s \\
\text { std. dev. }\end{array}$ & $\begin{array}{l}\text { Shipboard } \\
\text { report* }\end{array}$ & This study & $\begin{array}{l}\text { Shipboard } \\
\text { report* }\end{array}$ \\
\hline $\mathrm{SiO}_{2}(\mathrm{wt} \%)$ & 50.01 & 0.15 & 49.9 & 50.6 & 0.46 & 50.59 & 48.6 & 49.34 \\
\hline $\mathrm{TiO}_{2}$ & 2.76 & 0.04 & 2.71 & 1.00 & 0.02 & 0.97 & 0.42 & 0.39 \\
\hline $\mathrm{Al}_{2} \mathrm{O}_{3}$ & 13.80 & 0.06 & 13.8 & 14.6 & 0.26 & 14.59 & 15.9 & 15.99 \\
\hline $\mathrm{Fe}_{2} \mathrm{O}_{3}$ total & 12.53 & 0.09 & 12.2 & 11.3 & 0.14 & 11.16 & 11.2 & 11.15 \\
\hline $\mathrm{MnO}$ & 0.17 & 0.01 & 0.17 & 0.19 & 0.02 & 0.18 & 0.16 & 0.16 \\
\hline $\mathrm{MgO}$ & 7.31 & 0.04 & 7.23 & 8.21 & 0.10 & 8.02 & 9.23 & 9.22 \\
\hline $\mathrm{CaO}$ & 11.51 & 0.06 & 11.4 & 12.5 & 0.08 & 12.51 & 11.4 & 11.54 \\
\hline $\mathrm{Na}_{2} \mathrm{O}$ & 2.28 & 0.02 & 2.26 & 1.78 & 0.04 & 1.84 & 1.61 & 1.82 \\
\hline $\mathrm{K}_{2} \mathrm{O}$ & 0.52 & 0.01 & 0.52 & n.d. & n.d. & 0.003 & n.d. & 0.0024 \\
\hline $\mathrm{P}_{2} \mathrm{O}_{5}$ & 0.28 & 0.01 & 0.27 & 0.08 & 0.02 & 0.06 & 0.03 & 0.01 \\
\hline $\mathrm{H}_{2}^{+} \mathrm{O}^{+}$ & n.d. & n.d. & n.d. & 1.15 & 0.05 & 1.25 & 3.15 & 3.00 \\
\hline $\mathrm{Cr}(\mathrm{ppm})$ & 299 & 10 & 289 & 194 & 4 & 175 & 413 & 418 \\
\hline $\mathrm{Ni}$ & 114 & 2 & 121 & 81 & 3 & 84.1 & 128 & 134.5 \\
\hline $\mathrm{Cu}$ & 143 & 4 & 136 & 83 & 4 & 82.6 & 9 & 13.1 \\
\hline $\mathrm{Zn}$ & 103 & 2 & 105 & 78 & 2 & 75.8 & 65 & 60.7 \\
\hline $\mathrm{Ga}$ & 21 & 2 & 21 & 16 & 2 & n.d. & 12.6 & n.d. \\
\hline $\mathrm{Rb}$ & 11 & 1 & II & $<5$ & n.d. & $<0.4$ & $<5$ & $<0.4$ \\
\hline $\mathrm{Sr}$ & 400 & 5 & 403 & 47 & 2 & 44.5 & 50 & 51.7 \\
\hline $\mathrm{Y}$ & 26 & 2 & 28 & 27 & 2 & 25.9 & 12 & 11.0 \\
\hline $\mathrm{Zr}$ & 172 & 3 & 179 & 49 & 1 & 45.4 & 25 & 19.4 \\
\hline $\mathrm{Nb}$ & 19 & 1 & 19 & $<5$ & n.d. & 0.5 & $<5$ & $<0.3$ \\
\hline
\end{tabular}

Notes: n.d. = not determined; std. dev. = standard deviation

* Shipboard Scientific Party (1992).

Table 4. Reference data for the determination of $\mathrm{Fe}^{2 *}, \mathrm{~S}$, and $\mathrm{H}_{2} \mathrm{O}$.

\begin{tabular}{lccccc}
\hline Sample & Element & $\begin{array}{c}\text { This } \\
\text { study }\end{array}$ & $\begin{array}{c}2 \mathrm{~s} \\
\text { std. dev. }\end{array}$ & $\begin{array}{c}\text { Govindaraju } \\
(1989)\end{array}$ & $\begin{array}{c}\text { Lab } \\
\text { data }\end{array}$ \\
\hline MRG-1 & $\mathrm{S}$ & 310 & 26 & 313 & \\
GXR-2 & $\mathrm{S}$ & 644 & 40 & 610 & \\
Andesite & $\mathrm{Fe}^{2+}$ & 6.23 & 0.12 & & 6.28 \\
MRG-1 & $\mathrm{H}_{2} \mathrm{O}^{*}$ & 1.05 & 0.08 & 1.03 & \\
BE-N & $\mathrm{H}_{2} \mathrm{O}^{*}$ & 2.25 & 0.07 & 2.24 & \\
\hline
\end{tabular}

Note: std. dev, = standard deviation. 
Table 5. Modal compositions of selected Leg 137/140 diabase samples by XRD analysis.

\begin{tabular}{|c|c|c|c|c|c|c|c|c|c|c|c|c|c|c|c|c|}
\hline $\begin{array}{l}\text { Leg: } \\
\text { Core-section: } \\
\text { Interval }(\mathrm{cm}) \text { : } \\
\text { Piece no.: }\end{array}$ & $\begin{array}{c}137 \\
173 \mathrm{R} 01 \\
73-76 \\
9\end{array}$ & $\begin{array}{c}137 \\
186 \mathrm{R} 02 \\
30-32 \\
8\end{array}$ & $\begin{array}{c}140 \\
187 \mathrm{R} 01 \\
59-63 \mathrm{~A} \\
14\end{array}$ & $\begin{array}{c}140 \\
187 \mathrm{R} 01 \\
59-63 \mathrm{~B} \\
14\end{array}$ & $\begin{array}{c}140 \\
189 \mathrm{R} 01 \\
85-88 \\
19\end{array}$ & $\begin{array}{c}140 \\
190 \mathrm{R} 01 \\
10-14 \\
2\end{array}$ & $\begin{array}{c}140 \\
194 \mathrm{R} 01 \\
36-40 \\
7\end{array}$ & $\begin{array}{c}140 \\
196 \mathrm{R} 01 \\
21-26 \\
4\end{array}$ & $\begin{array}{c}140 \\
197 \mathrm{R} 01 \\
29-31 \\
7\end{array}$ & $\begin{array}{c}140 \\
198 \mathrm{R} 01 \\
50-54 \\
14\end{array}$ & $\begin{array}{c}140 \\
199 \mathrm{R} 01 \\
54-57 \\
13\end{array}$ & $\begin{array}{c}140 \\
200 \mathrm{R} 02 \\
53-57 \\
7 \mathrm{~B}\end{array}$ & $\begin{array}{c}140 \\
202 \mathrm{R} 01 \\
23-25 \\
7\end{array}$ & $\begin{array}{c}140 \\
204 \text { R01 } \\
15-19 \\
4\end{array}$ & $\begin{array}{c}140 \\
207 \mathrm{R} 01 \\
22-26 \\
6\end{array}$ & $\begin{array}{c}140 \\
209 \mathrm{R} 01 \\
98-102 \\
14\end{array}$ \\
\hline $\begin{array}{l}\text { Depth (mbsf): } \\
\text { Lithologic unit:* } \\
\text { Unit rock name: } \\
\text { Alteration (\%): } \\
\text { Alteration type: }\end{array}$ & $\begin{array}{c}1570.7 \\
193 \\
\text { OPC } \\
40 \\
\mathrm{~L}\end{array}$ & $\begin{array}{c}1628.1 \\
213 \\
\mathrm{AD} \\
35 \\
\mathrm{~L}\end{array}$ & $\begin{array}{l}1632.6 \\
216 \\
\text { sPCD } \\
25 \\
\text { D }\end{array}$ & $\begin{array}{l}1632.6 \\
216 \\
\text { sPCD } \\
90 \\
\text { P }\end{array}$ & $\begin{array}{l}1651.9 \\
218 \\
\mathrm{mPOCD} \\
12 \\
\mathrm{D}\end{array}$ & $\begin{array}{c}1655.2 \\
218 \\
\mathrm{mPOCD} \\
60 \\
\mathrm{P}\end{array}$ & $\begin{array}{c}1680.8 \\
220 \\
\mathrm{mPOCD} \\
20 \\
\text { D }\end{array}$ & $\begin{array}{l}1696.7 \\
222 \\
\mathrm{mPOCD} \\
15 \\
\text { D }\end{array}$ & $\begin{array}{c}1703.1 \\
222 \\
\text { mPOCD } \\
70 \\
\mathrm{H}\end{array}$ & $\begin{array}{l}1712.7 \\
223 \\
\text { sPOCD } \\
20 \\
\text { D }\end{array}$ & $\begin{array}{l}1719.9 \\
226 \\
\mathrm{mPOCD} \\
15 \\
\mathrm{D}\end{array}$ & $\begin{array}{c}1730.6 \\
227 \\
\mathrm{mPOCD} \\
10 \\
\mathrm{D}\end{array}$ & $\begin{array}{c}1747.4 \\
229 \\
\text { sPOCD } \\
25 \\
\mathrm{H}\end{array}$ & $\begin{array}{c}1756.7 \\
232 \\
\text { sPCOD } \\
45 \\
\mathrm{~L}\end{array}$ & $\begin{array}{c}1768.6 \\
236 \\
\mathrm{AD} \\
40 \\
\mathrm{D}\end{array}$ & $\begin{array}{l}1788.5 \\
240 \\
\text { mOPCD } \\
78 \\
P\end{array}$ \\
\hline $\begin{array}{l}\% \\
\text { Plagioclase } \\
\text { Amphibole } \\
\text { Chlorite } \\
\text { Clinopyroxene } \\
\text { Quartz } \\
\text { Talc } \\
\text { Sum }\end{array}$ & $\begin{array}{r}49 \\
15 \\
10 \\
27 \\
0 \\
0 \\
101\end{array}$ & $\begin{array}{r}42 \\
14 \\
14 \\
30 \\
0 \\
2 \\
102\end{array}$ & $\begin{array}{r}48 \\
16 \\
2 \\
33 \\
0 \\
0 \\
99\end{array}$ & $\begin{array}{r}30 \\
53 \\
5 \\
12 \\
0 \\
0 \\
100\end{array}$ & $\begin{array}{r}45 \\
11 \\
3 \\
37 \\
4 \\
2 \\
2 \\
102\end{array}$ & $\begin{array}{r}33 \\
37 \\
13 \\
16 \\
0 \\
0 \\
99\end{array}$ & $\begin{array}{r}42 \\
12 \\
3 \\
42 \\
2 \\
0 \\
0 \\
101\end{array}$ & $\begin{array}{r}45 \\
13 \\
3 \\
35 \\
4 \\
0 \\
100\end{array}$ & $\begin{array}{r}48 \\
28 \\
11 \\
13 \\
0 \\
0 \\
100\end{array}$ & $\begin{array}{r}48 \\
0 \\
7 \\
39 \\
0 \\
6 \\
100\end{array}$ & $\begin{array}{r}53 \\
0 \\
4 \\
38 \\
0 \\
5 \\
100\end{array}$ & $\begin{array}{r}53 \\
0 \\
2 \\
41 \\
0 \\
3 \\
99\end{array}$ & $\begin{array}{r}44 \\
10 \\
4 \\
41 \\
0 \\
0 \\
99\end{array}$ & $\begin{array}{r}46 \\
18 \\
6 \\
30 \\
0 \\
0 \\
100\end{array}$ & $\begin{array}{r}43 \\
35 \\
0 \\
22 \\
0 \\
0 \\
100\end{array}$ & $\begin{array}{r}34 \\
0 \\
19 \\
46 \\
0 \\
0 \\
99\end{array}$ \\
\hline
\end{tabular}

Notes: Unit rock name: $\mathrm{m}=$ moderately; $\mathrm{s}=$ sparsely; $\mathrm{O}=$ olivine; $\mathrm{P}=$ plagioclase $; \mathrm{C}=$ clinopyroxene; $\mathrm{D}=$ diabase; $\mathrm{A}=$ aphyric. Alteration type: $\mathrm{D}=$ macroscopically dark, less altered diabase; $\mathrm{L}=$ macroscopically light, high background alteration; $\mathrm{H}=$ diabase containing high percentage of halos around veins; $\mathrm{P}=$ samples with green patches or vugs and a high background alteration. *Shipboard Scientific Party (1992).

Table 5 (continued).

\begin{tabular}{|c|c|c|c|c|c|c|c|c|c|c|c|c|c|c|c|}
\hline $\begin{array}{l}\text { Leg: } \\
\text { Core-section: } \\
\text { Interval }(\mathrm{cm}) \text { : } \\
\text { Piece no.: }\end{array}$ & $\begin{array}{c}140 \\
209 \mathrm{R} 02 \\
68-70 \\
10\end{array}$ & $\begin{array}{c}140 \\
211 \mathrm{R} 01 \\
70-74 \\
16\end{array}$ & $\begin{array}{c}140 \\
213 \mathrm{R} 01 \\
64-68 \\
19\end{array}$ & $\begin{array}{c}140 \\
214 \mathrm{R} 01 \\
36-40 \\
5\end{array}$ & $\begin{array}{c}140 \\
216 \mathrm{R} 01 \\
54-56 \\
12\end{array}$ & $\begin{array}{c}140 \\
220 \mathrm{R} 01 \\
23-26 \\
6\end{array}$ & $\begin{array}{c}140 \\
222 \mathrm{R} 01 \\
69-73 \\
12 \mathrm{~A}\end{array}$ & $\begin{array}{c}140 \\
222 \mathrm{R} 01 \\
115-120 \mathrm{~A} \\
12\end{array}$ & $\begin{array}{c}140 \\
222 \mathrm{R} 01 \\
115-120 \mathrm{~B} \\
22\end{array}$ & $\begin{array}{c}140 \\
224 \mathrm{R} 01 \\
38-42 \\
8\end{array}$ & $\begin{array}{c}140 \\
225 \mathrm{R} 02 \\
29-32 \\
5\end{array}$ & $\begin{array}{c}140 \\
230 \mathrm{R} 01 \\
11-14 \\
3\end{array}$ & $\begin{array}{c}140 \\
235 \mathrm{R} 01 \\
21-24 \mathrm{~A} \\
7\end{array}$ & $\begin{array}{c}140 \\
235 \mathrm{R} 01 \\
21-24 \mathrm{~B} \\
7\end{array}$ & $\begin{array}{c}140 \\
238 \mathrm{R} 01 \\
4-7 \\
2\end{array}$ \\
\hline $\begin{array}{l}\text { Depth (mbsf): } \\
\text { Lithologic unit:* } \\
\text { Unit rock name: } \\
\text { Alteration (\%): } \\
\text { Alteration type: }\end{array}$ & $\begin{array}{l}1789.6 \\
240 \\
\text { mOPCD } \\
15 \\
\text { D }\end{array}$ & $\begin{array}{l}1799.2 \\
241 \\
\text { sPOCD } \\
30 \\
\text { D }\end{array}$ & $\begin{array}{l}1813.1 \\
243 \\
\text { sPOCD } \\
35 \\
\text { D }\end{array}$ & $\begin{array}{l}1819.0 \\
244 \\
\text { mPOCD } \\
50 \\
\text { D }\end{array}$ & $\begin{array}{l}1828.4 \\
245 \\
\text { mCOPD } \\
15 \\
\text { D }\end{array}$ & $\begin{array}{l}1865.7 \\
252 \\
\text { mCOPD } \\
10 \\
\text { D }\end{array}$ & $\begin{array}{l}1885.3 \\
254 \\
\text { mCOPD } \\
45 \\
\text { D }\end{array}$ & $\begin{array}{c}1885.8 \\
256 \\
\mathrm{AD} \\
45 \\
\mathrm{D}\end{array}$ & $\begin{array}{c}1885.8 \\
256 \\
\mathrm{AD} \\
70 \\
\mathrm{P}\end{array}$ & $\begin{array}{l}1904.1 \\
258 \\
\text { mCPOD } \\
8 \\
\text { D }\end{array}$ & $\begin{array}{l}1914.0 \\
260 \\
\text { mCOPD } \\
15 \\
\text { D }\end{array}$ & $\begin{array}{c}1953.1 \\
265 \\
\text { sPOCD } \\
40 \\
\text { L }\end{array}$ & $\begin{array}{c}1976.3 \\
269 \\
\text { mPOCD } \\
20 \\
\text { D }\end{array}$ & $\begin{array}{c}1976.3 \\
269 \\
\text { mPOCD } \\
45 \\
\text { H }\end{array}$ & $\begin{array}{l}1992.0 \\
269 \\
\text { mPOCD } \\
25 \\
\text { D }\end{array}$ \\
\hline $\begin{array}{l}\text { \% } \\
\text { Plagioclase } \\
\text { Amphibole } \\
\text { Chlorite } \\
\text { Clinopyroxene } \\
\text { Quartz } \\
\text { Talc } \\
\text { Sum }\end{array}$ & $\begin{array}{r}51 \\
0 \\
4 \\
41 \\
0 \\
4 \\
100\end{array}$ & $\begin{array}{r}47 \\
0 \\
6 \\
47 \\
0 \\
1 \\
101\end{array}$ & $\begin{array}{r}45 \\
10 \\
9 \\
36 \\
0 \\
0 \\
100\end{array}$ & $\begin{array}{r}44 \\
13 \\
8 \\
35 \\
0 \\
0 \\
100\end{array}$ & $\begin{array}{r}42 \\
0 \\
9 \\
49 \\
0 \\
0 \\
100\end{array}$ & $\begin{array}{r}40 \\
0 \\
4 \\
49 \\
5 \\
0 \\
98\end{array}$ & $\begin{array}{r}48 \\
0 \\
14 \\
38 \\
0 \\
0 \\
100\end{array}$ & $\begin{array}{r}33 \\
19 \\
12 \\
36 \\
0 \\
0 \\
100\end{array}$ & $\begin{array}{r}36 \\
32 \\
7 \\
26 \\
0 \\
0 \\
101\end{array}$ & $\begin{array}{r}39 \\
0 \\
2 \\
55 \\
0 \\
4 \\
100\end{array}$ & $\begin{array}{r}49 \\
0 \\
3 \\
48 \\
0 \\
1 \\
101\end{array}$ & $\begin{array}{r}38 \\
62 \\
0 \\
0 \\
0 \\
1 \\
101\end{array}$ & $\begin{array}{r}50 \\
12 \\
2 \\
35 \\
0 \\
0 \\
99\end{array}$ & $\begin{array}{r}40 \\
39 \\
2 \\
19 \\
0 \\
0 \\
100\end{array}$ & $\begin{array}{r}44 \\
11 \\
4 \\
42 \\
0 \\
1 \\
102\end{array}$ \\
\hline
\end{tabular}

